\title{
Open Access Monitor - DK (OAM-DK): Indsamling, dokumentation og administration af publiceringsudgifter til Open Access i Danmark
}

Svendsen, Michael; Andersen, Dorte; Rosenkrantz Hansen, Claus; Thomsen, Louise; Katberg, Lone Ramy; Blaabjerg, Niels Jørgen; Morthorst, Anna Mette; Christensen, Vibeke; Brejnebøl, Birgit; Sand, Ane Ahrenkiel

Total number of authors:

18

Link to article, DOI:

10.7146/aul.291.205

Publication date:

2018

Document Version

Publisher's PDF, also known as Version of record

Link back to DTU Orbit

Citation (APA):

Svendsen, M., Andersen, D., Rosenkrantz Hansen, C., Thomsen, L., Katberg, L. R., Blaabjerg, N. J., Morthorst, A. M., Christensen, V., BrejnebøI, B., Sand, A. A., Schneider, A. W., Pedersen, C. D., Mikkelsen, L. I., Hansen, L. A. J., Hansen, B. A., Schelde, S., Thorst Melbye, A., \& Worm Thomsen, L. (2018). Open Access Monitor-DK (OAM-DK): Indsamling, dokumentation og administration af publiceringsudgifter til Open Access i Danmark. DEFF. https://doi.org/10.7146/aul.291.205

\section{General rights}

Copyright and moral rights for the publications made accessible in the public portal are retained by the authors and/or other copyright owners and it is a condition of accessing publications that users recognise and abide by the legal requirements associated with these rights.

- Users may download and print one copy of any publication from the public portal for the purpose of private study or research.

- You may not further distribute the material or use it for any profit-making activity or commercial gain

- You may freely distribute the URL identifying the publication in the public portal 


\section{Open Access Monitor - DK (OAM-DK)}

Indsamling, dokumentation og administration af publiceringsudgifter til Open Access i Danmark

\section{OPEN ACCESS MONITOR - DK \\ Collection, documentation and administration of Open Access publication costs in Denmark}

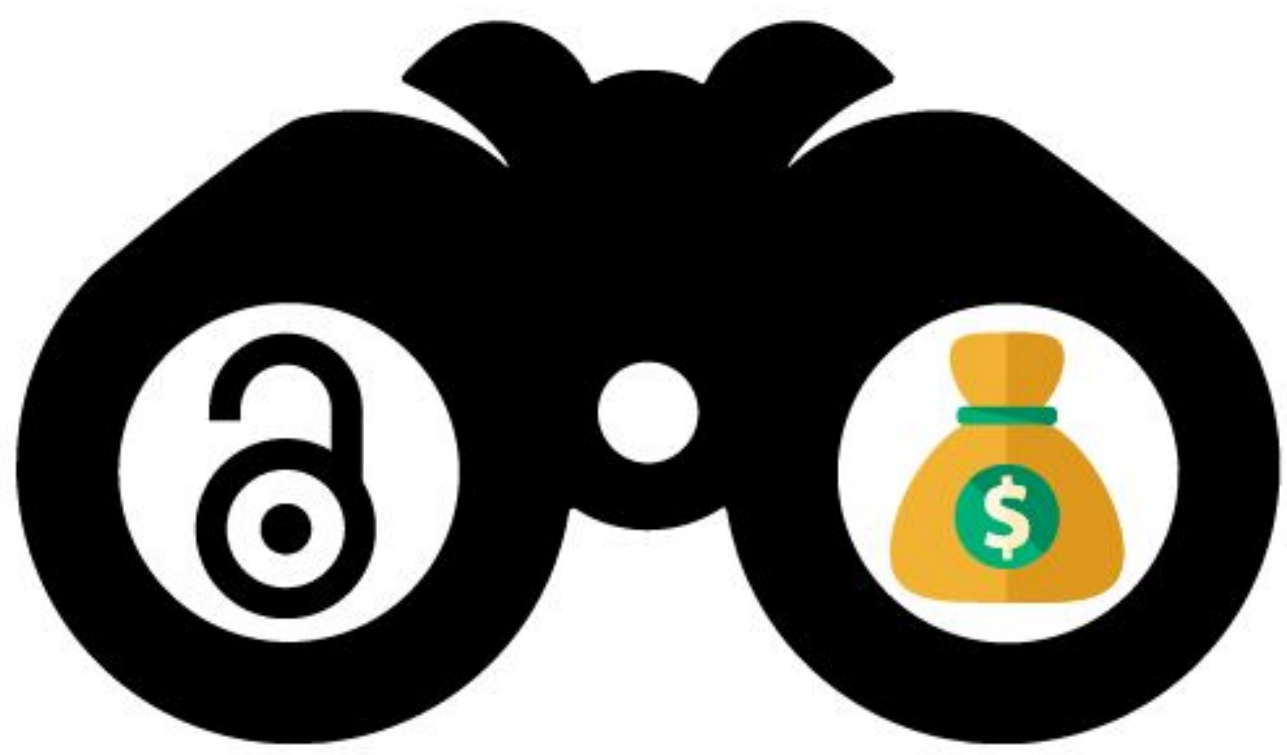

Resultater, anbefalinger og evaluering

December 2018

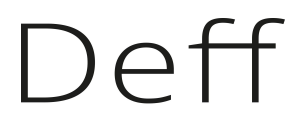

Danmarks Elektroniske

Fag- og Forskningsbibliotek




DEFF rapporten for OAM-DK projektet er forfattet af:

Michael Svendsen: Det Kgl. Bibliotek, Københavns Universitetsbibliotek, (iD orcid.org/0000-0002-5807-5326 Dorte Andersen, Det Kgl. Bibliotek, Københavns Universitetsbibliotek

Claus Rosenkrantz Hansen, Copenhagen Business School

Bidragsydere og deltagende kolleger i OAM-DK projektet kommer fra følgende institutioner:

Aalborg Universitet (AAU): Louise Thomsen, Lone Ramy Katberg, Niels Jørgen Blaabjerg Aarhus Universitet (AU): Anna Mette Morthorst (tovholder: B.2), Vibeke Christensen Copenhagen Business School (CBS): Birgit Brejnebøl, Claus Rosenkrantz Hansen (tovholder B.3)

Danmarks Tekniske Universitet (DTU): Ane A. Sand, Anette W. Schneider (tovholder B.4), Christian Pedersen, Lise Mikkelsen

Det Kgl. Bibliotek (KB): Asger Juel Hansen, Britt A. Hansen (tovholder A.3), Dorte Andersen (tovholder A.1), Michael Svendsen (projektleder, tovholder A.2)

Roskilde Universitet (RUC): Sidse Schelde

Syddansk Universitet (SDU): Anne Thorst Melbye (tovholder B.1), Lærke W. Thomsen

ISBN: 978-87-7507-438-9

DOI: 10.7146/aul.291.205

45 sider.

København, December 2018

Denmark's Electronic Research Library (DEFF) 
0 Abstract (in English) $\quad 4$

1 Baggrund $\quad 5$

2 Indledning $\quad 6$

3 Rapportens struktur $\quad 7$

4 Hovedfaser og arbejdsspor $\quad 8$

4.1 Fase A:

Monitorering af national Open Access publiceringsøkologi - og økonomi 8

4.1.1 Kortlægning af lignende projekter, metoder, institutionelle aftaler, business modeller og funding flows (A.1). 8

4.1.2 Dataindsamling: kilder, udtræk og konsolidering af indsamlingsmetode (A.2). $\quad 10$

4.1.3 Etablering af workflow (best practice) på tværs af projektets deltagende institutioner (A.3). 14

4.1.4 Beregning på omfang af gylden og hybrid OA samt afledte APC udgifter (A.4) 17

4.1.5 Implementering af databeregninger i infrastruktur samt udstilling/visualisering i OA indikator (A.5) 19

4.1.5.1 Udkast til specifikation og mock-up: OA Monitor 19

4.1.6 Involvering af eksterne partnere (A.6) 25

4.2 Fase B:

Identifikation og udvikling af best practice for APC-administration 26

4.2.1 Afdække nuværende lokale praksis på universiteterne (B.1) 26

4.2.2 Unders $\varnothing$ gelse af central apc-administration, invoice systemer samt udenlandske

erfaringer (B.2) 27

4.2.3 Udvikle anbefaling til en national best practice på baggrund af institutionernes behov (B.3)

4.2.3.1 Spor B1. Afdække nuværende lokal praksis på universiteterne 31

4.2.3.2 Spor B2. Undersøgelse af central APC-administration, invoice-systemer, udenlandske erfaringer $\mathrm{mm}$. 32

4.2.3.2.1 JISC Monitor Local og Monitor UK 33

4.2.3.2.2 OpenAPC og OpenAPC Sweden 34

4.2.3.2.3 Chronos 36

4.2.3.3 Opsummerende på de ovenfor beskrevne løsninger 37

4.2.4 Anbefalinger til national best practice (B.3) 39

$\begin{array}{ll}5 \text { Konklusion } & 40\end{array}$

6 Perspektivering $\quad 41$

$\begin{array}{ll}7 \text { Referencer } & 43\end{array}$

8 Appendix $\quad 44$

$\begin{array}{ll}9 \text { Figurer } & 44\end{array}$ 


\section{Abstract (in English)}

\section{Open Access Monitor project (OAM-DK)}

In a changing landscape of new Open Access modes, Denmark has adopted a so-called green Open Access strategy, according to which publications must be kept largely free of charge and publications must be archived in institutional repositories.

Even so, Danish universities spend significant financial resources on Open Access publishing. Substantial fees are being paid to publish via the golden route in Open Access journals, but also in subscription-based journals via the hybrid model. The latter is especially interesting considering the practice of double-dipping, where universities not only pay for the right-to-read (via the national e-license portfolios) but also for the right-to-publish (via publication fees).

This raises the question of the scale of resources being spent on Open Access publishing by Danish universities. This DEFF project follows similar efforts in the UK, Sweden, Norway, Germany and the Netherlands, monitoring how much is being spent on gold and hybrid publishing by Danish universities. The approach has been to identify the publishing ecology of Open Access and derived financial costs. Since it is difficult to gather invoice data, an economic model has been developed to estimate the total cost of publication at Danish universities.

Results show that both gold and hybrid expenses related to Open Access publishing in the Danish universities are increasing substantially and that monitoring efforts are required.

An executive summary has been produced prior to the programme of the OAM-DK Concluding Conference and are both available here: $10.5281 /$ zenodo.1544953.

Read more about the project: $\underline{\text { bit.ly/oam-dk }}$

The participating institutions would like to thank:

DEFF: Denmark's Electronic Research Library for financial support.

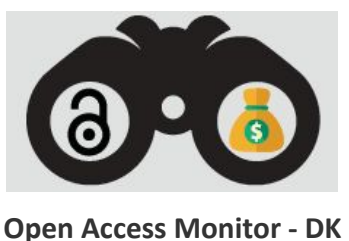




\section{Baggrund}

Open Access Monitor - DK er et 2-årigt ansøgt projekt med en godkendt bevilling på 2,5 mio. DKK ${ }^{1}$ under udviklingspuljen hos DEFF i følgende indsatsområder i årene 2017-2018²:

- Adgang til digital videnskabelig viden

- Videnspredning, forskningsanalyser og bibliometri

- Konsolidering

Det overordnede formål med OAM-DK er at etablere ensartede workflows og standarder for indsamling, dokumentation og administration af publiceringsudgifter til Open Access på de danske universiteter. Ved at opstille en række klare projektmål, der ønsker at undersøge muligheden for at indsamle sammenlignelige og valide data på henholdsvis omfanget af typer af publiceret Open Access og udgifter forbundet hermed for dansk forskning, er det målet at udviklingen kan monitoreres over tid.

OAM-DK projektets involverede partnere har i projektperioden 2017-2018 arbejdet efter nedenstående tidsplan og haft tovholdere på hvert arbejdsspor som et bredt samarbejde blandt forskningsbibliotekerne ved AAU, AU, CBS, DTU, KB/KUB, RUC og SDU. Ejerskabet og ledelsen af projektet har været forankret hos Københavns Universitetsbibliotek, KUB.

\begin{tabular}{|c|c|c|c|c|c|c|c|c|c|c|}
\hline \multirow{2}{*}{$\begin{array}{l}\text { Tidsplan: OAM-DK } \\
\text { Hovedfaser }\end{array}$} & \multirow[b]{2}{*}{ Arbejdsspor } & \multirow{2}{*}{\begin{tabular}{|l|} 
Institutioner \\
\end{tabular}} & \multicolumn{4}{|c|}{2017} & \multicolumn{4}{|c|}{2018} \\
\hline & & & 1. kvartal & 2. kvartal & 3. kvartal & 4. kvartal & 1. kvartal & 2. kvartal & 3. kvartal & 4. kvartal \\
\hline Opstart & Projektplanlægning & KB/KUB & & & & & & & & \\
\hline \multirow{6}{*}{$\begin{array}{l}\text { A: Monitorering af } \\
\text { national OA } \\
\text { publiceringsøkologi og - } \\
\varnothing \text { konomi }\end{array}$} & $\begin{array}{l}\text { 1. Kortlægning af lign. projekter, metoder, } \\
\text { institutionelle aftaler, business modeller } \\
\text { og funding flows }\end{array}$ & $R U B, K B / K \cup B, S D U B$ & & & & & & & & \\
\hline & $\begin{array}{l}\text { 2. Dataindsamling; kilder, udtræk og } \\
\text { konsolidering af indsamlingsmetode }\end{array}$ & $\begin{array}{l}\text { DTUB, CBS, AUB, SDUB, } \\
\text { RUB, KB/KUB, AUL }\end{array}$ & & & & & & & & \\
\hline & 3. Etablering af workflow (best practice) & \begin{tabular}{|l|} 
DTUB, CBS, AUB, \\
SDUB, RUB, KB/KUB,
\end{tabular} & & & & & & & & \\
\hline & $\begin{array}{l}\text { 4. Beregning på omfang af gylden, hybrid } \\
\text { og grøn OA samt afledte udgifter (apc) }\end{array}$ & $\begin{array}{l}\text { DTUB, CBS, AUB, } \\
\text { SDUB, KB/KUB, AUL }\end{array}$ & & & & & & & & \\
\hline & $\begin{array}{l}\text { 5. Implementering af databeregninger i } \\
\text { infrastruktur samt udstilling/visualisering i } \\
\text { OA indikator tal for } 2016\end{array}$ & DTUB, DTU, KB/KUB & & & & & & & & \\
\hline & $\begin{array}{l}\text { 6. Hackathon/datasprint på datasæt }-\mathrm{m} \text {. } \\
\text { involvering af eksterne partnere: fx. OKNF. } \\
\text { DK }\end{array}$ & $D T U B, K B / K U B$ & & & & & & & & \\
\hline \multirow{3}{*}{$\begin{array}{l}\text { B: Identifikation og } \\
\text { udvikling af best practice } \\
\text { for APC administration }\end{array}$} & 1. Lokal praksis på universiteterne & \begin{tabular}{|l} 
DTUB, CBS, AUB, SDUB, \\
RUB, KB/KUB, AUL
\end{tabular} & & & & & & & & \\
\hline & $\begin{array}{l}\text { 2. Undersøgelse af central apc- } \\
\text { administration, invoice systemer m.m. }\end{array}$ & $\begin{array}{l}\text { DTUB, CBS, AUB, SDUB, } \\
\text { KB/KUB, AUL }\end{array}$ & & & & & & & & \\
\hline & $\begin{array}{l}\text { 3. Udvikle anbefaling til national best } \\
\text { practice på baggrund af institutionernes } \\
\text { behov }\end{array}$ & $\begin{array}{l}\text { DTUB, KB/KUB, AUL, } \\
\text { SDUB, CBS }\end{array}$ & & & & & & & & \\
\hline \multirow{2}{*}{ Afslutning } & 1. Publicering af rapport/white paper & KB/KUB & & & & & & & & \\
\hline & $\begin{array}{l}\text { 2. Planlægning og afholdelse af } \\
\text { konference }\end{array}$ & KB/KUB & & & & & & & & \\
\hline
\end{tabular}

I projektperioden er der afholdt et kick-off-møde, fem ordinære projektm $\varnothing$ der, tre styregruppem $\varnothing$ der samt to workshops (se Appendix 1); heraf en international workshop, hvor forskellige eksisterende løsninger til OA-monitorering blev gennemgået samt en dataworkshop om den udviklede metode til dataindsamling for bedst muligt at klæde de deltagende institutioner på ${ }^{3}$.

\footnotetext{
${ }^{1}$ Se projektansøgningen og statusrapporter aflagt undervejs i projektet: $\underline{\text { https://bit.ly/oam-dk }}$

${ }^{2}$ DEFF (2016): Åbenhed, adgang og deling, DEFF workshop, 9. marts, 2016: https://www.deff.dk/fileadmin/user upload/DEFF/dokumenter/strategi og samarbejde/DEFF-Workshop/Deff Strategi B eta.pdf

${ }^{3}$ OAM-DK Workshop: At høste metadata fra API'er og få nye data, 23.1.2018, KB Aarhus:

https://github.com/enemydown-dk/oam dk workshop
} 


\section{Indledning}

I en konstant foranderlig digital publicerings $\varnothing$ kologi, der internationalt skubbes mod $\varnothing$ get videnskabelig publicering i Open Access (jf. den seneste europæiske initiering af cOAlition S og lancering af Plan $\mathrm{S}^{4}$ ), er det blevet en $n \varnothing$ dvendighed for institutioner involveret i offentlig finansieret forskning at monitorere og benchmarke publikations -og udgiftsdata på et aggregeret nationalt og internationalt niveau, der relaterer sig til forskellige typer af forretningsmodeller, der løbende modificeres og lanceres blandt de internationale udbydere og forlag.

Både internationale fundere, organisationer og universiteter er i de seneste år mere aktivt begyndt at initiere og fokusere på understøttende aktiviteter, der kan monitorere udviklingen inden for Open Access. Denne udviklingstendens er drevet dels af strategier og politikker på området, men også af bekymringer om, at $\emptyset$ konomiske udgifter, der investeres i nye OA-modeller på markedet, ikke er transparente og bæredygtige og kan ende med at lede til uhensigtsmæssigt øgede omkostninger på et i forvejen meget centreret og monopolbåret publiceringsmarked. Denne bekymring er senest blevet udtrykt i en samlet klage, initieret af Danske Universiteter ${ }^{5}$ og bakket op af EUA (European University Association) ${ }^{6}$ til ECs konkurrencekommissær Margrethe Vestager, der beder om samlet at se nærmere på den manglende konkurrence i de videnskabelige forlags monopol-strukturer.

Sideløbende har også proaktive aktører som velgørende foundations lanceret nye åbne publiceringsplatforme ${ }^{7}$, der $\emptyset$ nsker at tilbyde services til forskere og universiteter, der kan sikre overholdelse af indgåede kontrakter med fundere samtidigt med at de administrative omkostninger lettes.

Det politiske pres på udviklingen hen imod Open Access går ufatteligt stærkt i disse år og med andre ord ser det i horisonten ud til at monitorering af publikations -og udgiftsdata vil være en nødvendig forudsætning at tilvejebringe for at være i stand til at sikre en bæredygtighed i allokeringen af de institutionelle budgetter, der sikrer adgang til forskning i en periode, hvor der sættes $\varnothing$ konomiske begrænsninger for væksten på de offentlige forskningsbudgetter.

Open Access Monitor - DK har i projektperioden for første gang nogensinde sat sig som mål at kortlægge den samlede publicerings $\varnothing$ kologi for Open Access og de økonomisk afledte udgifter til publicering på vegne af de danske universiteter i Danmark. Denne rapport leverer på den baggrund en række klare anbefalinger til de identificerede stakeholders, der indgår i såvel finansieringen som tilvejebringelsen af Open Access publiceret forskning i Danmark.

\footnotetext{
${ }^{4}$ cOAlition S: Making Open Access a reality by 2020 - A Declaration of Commitment by Public Research Funders (September 4, 2018): https://www.scienceeurope.org/coalition-s/

${ }^{5}$ Danske Universiteter (pressemeddelse, 6. nov. 2018): “Danske universiteter går til Vestager for at stoppe forlagsmonopol": https://dkuni.dk/pressemeddelelser/danske-universiteter-gaar-til-vestager-for-at-stoppe-forlagsmonopol L

${ }^{6}$ EUA (press release, Nov 6, 2018) Scholarly publishing: EUA asks European Commission to investigate lack of competition:https://eua.eu/news/188:scholarly-publishing-eua-asks-european-commission-to-investigate-lack-of-competit ion.html

${ }^{7}$ Bl.a. Wellcome Open Research: https://wellcomeopenresearch.org/, Gates Open Research: https://gatesopenresearch.org/ og den Europæiske Kommissions udbud på Open Research Europe: https://etendering.ted.europa.eu/cft/cft-display.html?cftld=3418
} 


\section{Rapportens struktur}

Rapporten er opbygget efter samme struktur, som etableringen af arbejdspakkerne i projektans $\varnothing$ gningens to hovedspor (Fase A og B) med de aftalte og underliggende arbejdsspor.

Rapporten tilstræber i en letlæselig tekstform at kunne tilvejebringe en enkel og ukompliceret læseoplevelse, der ikke kræver særlige forudsætninger for læseren og samtidigt ikke fortaber sig i tekniske detaljer fra de enkelte arbejdsspor.

Rapporten fokuserer på at fremhæve de nationale resultater i OAM-DK projektet, hvor der er konsensus om at udstikke særlige anbefalinger vedr. både udfordringer og muligheder baseret på erfaringerne i projektperioden. Der vil i rapporten løbende blive henvist til Appendixet, der indeholder mestendelen af hovedresultaterne i de enkelte opsamlende dokumenter, der er produceret undervejs i projektets forløb som aftalte delmål, og som der vil blive henvist til løbende gennem rapporten.

Hovedlinjen i rapporten fors $\varnothing$ ger med andre ord at skabe en gennemgående rød tråd i læseoplevelsen, der fluktuerer fra samarbejdet om de udviklede processer over de anvendte fremgangsmåder til de frembragte resultater, der slutteligt peger mod de endelige anbefalinger til relevante stakeholders.

God læselyst!

På vegne af

OAM-DK projektet

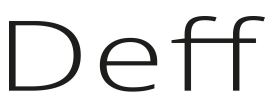

Danmarks Elektroniske

Fag- og Forskningsbibliotek

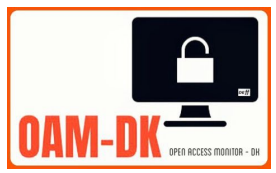




\section{Hovedfaser og arbejdsspor}

\subsection{Fase A:}

\section{Monitorering af national Open Access publicerings økologi - og økonomi}

Fase A: Monitorering af national Open Access publicerings $\varnothing$ kologi - og $\varnothing$ konomi

Fase A er struktureret omkring 6 arbejdsspor, der vil identificere og løbende udvikle samt dokumentere de bedst egnede arbejdsmetoder for indsamling og beregning af data til gavn for bedre monitorering af den danske Open Access publicerings $\varnothing$ kologi og $\varnothing$ konomi.

1. Kortlægning af lign. projekter, metoder, institutionelle aftaler, business modeller og funding flows.

2. Dataindsamling: datakilder, dataudtræk og konsolidering af indsamlingsmetode.

A) identifikation og overblik over gyldne og hybride OA-publikationer $(2015,2016)$

B) udvikling, beskrivelse og dokumentation af indsamlingsmetodik.

3. Etablering af workflow (best practice) på tværs af projektets deltagende institutioner.

4. Beregning på omfang af gylden og hybrid OA samt afledte APC-udgifter.

5. Implementering af databeregninger i infrastruktur samt udstilling/visualisering i $O A$ indikator.

6. Involvering af eksterne partnere og interessenter.

\subsubsection{Kortlægning af lignende projekter, metoder, institutionelle aftaler, business modeller og funding flows (A.1).}

Spor A1 havde til formål at kortlægge:

- Lignende projekter, business modeller og funding flows, som allerede til dels var kendte ved OAM-DK-projektets opstart.

- Licensaftaler med Open Access vilkår for 2015 og 2016 til brug i det videre arbejde med de endelige beregninger af APC-udgifter.

Sporet var tidsmæssigt planlagt til at løbe fra februar til juni 2017 og havde deltagelse af KB/KUB og SDU. Dertil blev andre relevante fagpersoner på alle deltagende institutioner bedt om at bidrage.

Indledningsvis blev der samlet op på de aktiviteter, som allerede var i gang som processer $\mathrm{i}$ licensforvaltninger på de enkelte deltagende institutioner. I december 2016 blev der ligeledes udgivet en delrapport ${ }^{8}$ til et internt projekt i KUB med titlen "E-ressource/Open Access Strategi", der indeholdt en overskuelig oversigt over de Open Access modeller, som bl.a. forlagene opererer med.

Der er flere af projektets deltagere, som enten er eller har været involveret i internationale projekter eller samarbejder som fx Knowledge Exchange, der er et nordeuropæisk netværk, der bl.a. har arbejdet

\footnotetext{
${ }^{8}$ E-ressource/Open Access Strategi: Rapport om OA forretningsmodeller på markedet. Michael Svendsen. 2016 (se Appendix 2).
} 
koncentreret med monitorering af Open Access og APC- $\varnothing$ konomien, senest ved en international workshop, som KB var vært for i København i efteråret 2016, og hvor flere af OAM-DK-projektets deltagere var med. Workshoppen resulterede i en rapport med en række anbefalinger til politikker, strategier og best practices på området. ${ }^{9}$

Projektdeltagere fra SDU deltager også i projektet OpenAire, som har til formål at udbrede kendskabet til Open Access. En del af denne opgave er at informere om de krav og muligheder, som EU som bevillingsgiver stiller til modtagerne af forskningsbevillingerne fra hhv. FP7 og Horizon2020 om Open Access- og Open Data-publicering. Der fokuseres i øjeblikket på at kæde bevillinger sammen med publikationer, så bevillingsgiverne kan følge med i, hvilke publikationer bevillingerne resulterer i.

OpenAIRE har i løbet af projektets levetid udviklet sig fra at udgøre et repository for Open Access-publikationer til at være en aggregator af publikationer (artikler, bøger, rapporter, datasæt mv) fra andre repositorier rundt om i Europa. OpenAIRE arbejder sammen med ERC's Participant Portal, så det sikres, at de krav til OA-publicering, der ligger i FP7 og Horizon 2020-programmerne, lever man op til ved at lægge en OA-publikation i OpenAIRE, da der automatisk linkes til Participant Portal. På den måde er OpenAIRE ved at udvikle sig til en mere omfattende infrastruktur end blot et OA-arkiv.

Projektdeltagere har hver især også løbende haft kontakt til forskellige forskningsfonde angående deres funding flows og mulige behov og ønsker:

- Villum Fonden - har haft bes $\varnothing \mathrm{g}$ af projektdeltagere om OpenAIRE.

- Novo Nordisk Fonden - har været i dialog med KU SUND og KUB om mulige tiltag

- Lundbeck Fonden - deltager på OAM-DK afslutningskonferencen.

Alle fondene har indkøbt ResearchFish ${ }^{10}$ til monitorering af projekters output, men det mangler at blive afklaret, om de endnu har data i systemerne, og om de danske fonde vil indgå i et fremtidigt samarbejde, da OAM-DK projektet formoder, at der kunne være fælles data points af gensidig interesse.

Det er en løbende opgave at indgå i samarbejdet med internationale samarbejdspartnere som fx Knowledge Exchange og OpenAIRE m. fl. Derfor er den ikke be- eller afgrænset af dette projekt (se i øvrigt afsnit 4.1.6).

Dertil blev de deltagende institutioner bedt om at levere information i et oversigtsskema over de licensaftaler, som findes på institutionerne og hvor Open Access er forhandlet ind i aftalen. Kort beskrevet er skemaet bygget op sådan, at aftalerne som udgangspunkt er delt ind i:

- Aftaler via konsortielicensaftaler (blå)

- Aftaler via universitetet (grøn)

- Aftaler via universitetsbiblioteket (grå)

\footnotetext{
9 "Knowledge Exchange consensus on monitoring Open Access publications and cost data: Report from workshop held in Copenhagen 29-30 November 2016": http://www.knowledge-exchange.info/event/oa-monitoring

${ }^{10}$ ResearchFish er et online system, som kan administrere og monitorere funding og projekt output i en institution: https://www.researchfish.net/funders
} 
Dernæst er hver blok delt op i 2015 og 2016, som er de år, hvor der bliver trukket data om OA-publicering.

Hver institution har meldt ind med, hvilke aftaler de er med i, og hvilke vilkår (hybrid, gylden, grøn) der gælder i aftalerne. Vilkårene er beriget med uddybende oplysninger om f.eks. procentsatser for rabat på APC eller et antal vouchers, som institutionen er tildelt, samt en titelliste for aftalen. Det samme er gældende for licensaftalerne. Oplysningerne bliver for nuværende holdt inden for projektets rammer og bliver evt. kun offentliggjort i forbindelse med de nationale beregninger af APC-udgifter.

Selve oversigtsskemaet indeholder alle licensaftaler med forhandlede OA-vilkår. Som et brugbart redskab for de endelige beregninger af APC-priser, ligger der dog en begrænsning $i$, at det udelukkende medtager 2015 og 2016 aftaler, hvorfor det manuelt skal vedligeholdes og opdateres, hvis det skal have en værdi fremadrettet.

Udtrækket af publikationer fra universiteternes PURE skal matches med oversigten over licensaftaler med Open Access forhandlede vilkår og dermed danne grundlag for en beregning af APC-udgifter. Målet er at skabe et overblik over, om den enkelte institution har en OA-aftale på et tidsskrift eller en licens på et tidsskrift, hvor en artikel er publiceret hybridt. På den baggrund kan det derefter konstateres, om der evt. er foregået double dipping. Det færdige oversigtsskema ligger pt. kun tilgængeligt for projektdeltagerne på OAM-DK projektets styringsværktøj i Confluence (se Appendix 3: Kortlægningsskema).

\subsubsection{Dataindsamling: kilder, udtræk og konsolidering af indsamlingsmetode (A.2).}

A. Identifikation og overblik over gyldne og hybride OA publikationer

B. Udvikling og beskrivelse af indsamlingsmetodik

Formålet med spor A.2 har været tosidig. For det første har sporet skullet identificere og levere et nationalt overblik over publiceringsøkologien for danske universiteters gyldne og hybride OA-publikationer. For det andet har sporet skullet udvikle og beskrive en valid indsamlingsmetode, der skulle fungere som basis for et estimeret overblik over institutionelle som nationale udgifter til APC (article processing charge) for årene 2015 og 2016.

Der er blevet arbejdet med at identificere to metoder for dataindsamling:

1. Et eksempel på en metode, der baserer sig på muligheden for at få identificeret og udtrukket reelle $\varnothing$ konomiske data i form af faktureringer fra institutioners $\varnothing$ konomisystemer med henblik på at vise, hvor meget det enkelte universitet reelt betaler i publiceringsudgifter.

2. En (delvis) automatiseret arbejdsgang og model for indsamling af data til at estimere APC-udgifterne for danske universiteter, baseret på de publikationer, der indgår som genstandsfelt i den danske OA indikator ${ }^{11}$.

1. Som case på et universitets udgifter er der tidligt i projektet på fors øgsbasis blevet leveret et udtræk af faktureringer fra Aalborg Universites (AAU) økonomisystem og beskrevet, hvordan dette mere generelt kan realiseres.

\footnotetext{
${ }^{11}$ Den danske Open Access Indikator (OAI): http://oaindikator.dk/da
} 
De umiddelbare erfaringer og resultater er kommet i stand efter et møde mellem deltagere fra OAM-DK-projektet og AAUs økonomiafdeling, repræsenteret af den faglige leder for Bogholderi og Rejsekontor, der forud for mødet var blevet gjort bekendt med OAM-DK-projektet.

Ønsket om at se et udtræk særligt for publiceringsudgifter for AAU har vakt genklang ift., at $\varnothing$ konomiafdelingen allerede er i gang med at rydde op og fokusere de kontostrenge, som der benyttes på universitetet. Dette har for AAU muliggjort, at det på sigt måske vil være lettere at appellere til, at der indføres en speciel kontostreng for APC-betaling på universitetet.

AAU-casen har bevirket at:

- Kontostrenge/artskonto ${ }^{12}$ for AAUs Indk $\varnothing$ bsafdeling er blevet beskrevet

- Det vil være under KØB AF VARER OG TJENESTEYDELSER ${ }^{13}$, at der skal kunne findes evt. udgifter til APC.

- I gennemgangen af artskonto 14 identificerede projektdeltagere fra AAU sammen med $\varnothing$ konomimedarbejderen fem konti, som der formodentlig vil være relevante hits på:

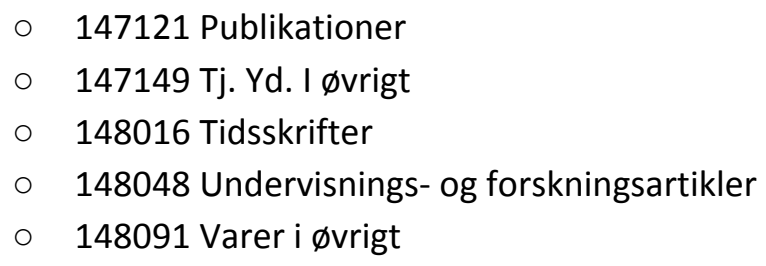

- Alle betalinger, der er blevet lavet på disse kontostrenge i 2015, har projektdeltagerne på casen fra AAU fået tilsendt som et udtræk i en Excel-fil, der ligger på projektsitet $\mathrm{i}$ Confluence.

Herefter skal der gives adgang til Qlikview ${ }^{14}$, hvor man ville kunne se de enkelte fakturaer. Hvis fakturaen ikke er nok til at kunne identificere udgiften, kan der tages kontakt til de enkelte forlag. For betalinger lavet på kort/rejseafregning vil der skulle foretages en henvendelse til det enkelte institut. Målet er at kunne finde en betaling og koble den med en artikel og en unik DOI.

2. Sideløbende blev det af projektledelsen besluttet at basere en national indsamlingsmetode på dataudtræk for publikationsårene 2015 og 2016 fra den danske OA Indikator. OAI høster allerede publikationsdata fra de danske universiteters PURE ${ }^{15}$, men dataene indeholder ikke alle nødvendige metadata for at kunne levere et estimat på udgifterne.

Der vil typisk, hvilket erfaringerne fra sporet også har bevidnet, være inkonsistens mellem behovet for (meta)data og tilgængelige (meta)data inden for egne institutioner. Derfor er OAl-data blevet sammenholdt med høstning af en række eksterne 3. parts datakilder, der har skullet aggregeres og kombineres på nye måder for at skabe nye indsigter.

\footnotetext{
12 http://regnforv.aau.dk/kontoplan/kontoplan?Plan=Artskonto

${ }^{13}$ http://regnforv.aau.dk/kontoplan/kontoplan?Plan=Artskonto\&CurrentGroup=14\&Level=2

${ }^{14}$ https://www.qlik.com/us/products/qlikview

${ }_{15}$ PURE er oprindeligt et CRIS og RIM-system udviklet af den danske virksomhed Atira (http://www.atira.dk), men er nu en del af Elsevier (https://www.elsevier.com/solutions/pure).
} 
Metoder som fil-processering af forskellige formater, API-queries mod datakilder, oprensning og normalisering af data samt programmering og anvendelse af scripts har alle været $n \varnothing d v e n d i g e$ for en systematisk og ensartet indsamling af data til projektets behov.

Processen har ikke været ligetil, og det har krævet en grundig udvikling og dialog at nå frem til en best practice praktisk vejledning, der gennemløber et workflow, som alle institutioner har skullet fors $\emptyset$ ge at håndtere i deres dataindsamling for egne universiteters publikationer (se afsnit 4.1.3).

Ideelt set kan man tale om en proces, der gennemgår følgende faser:

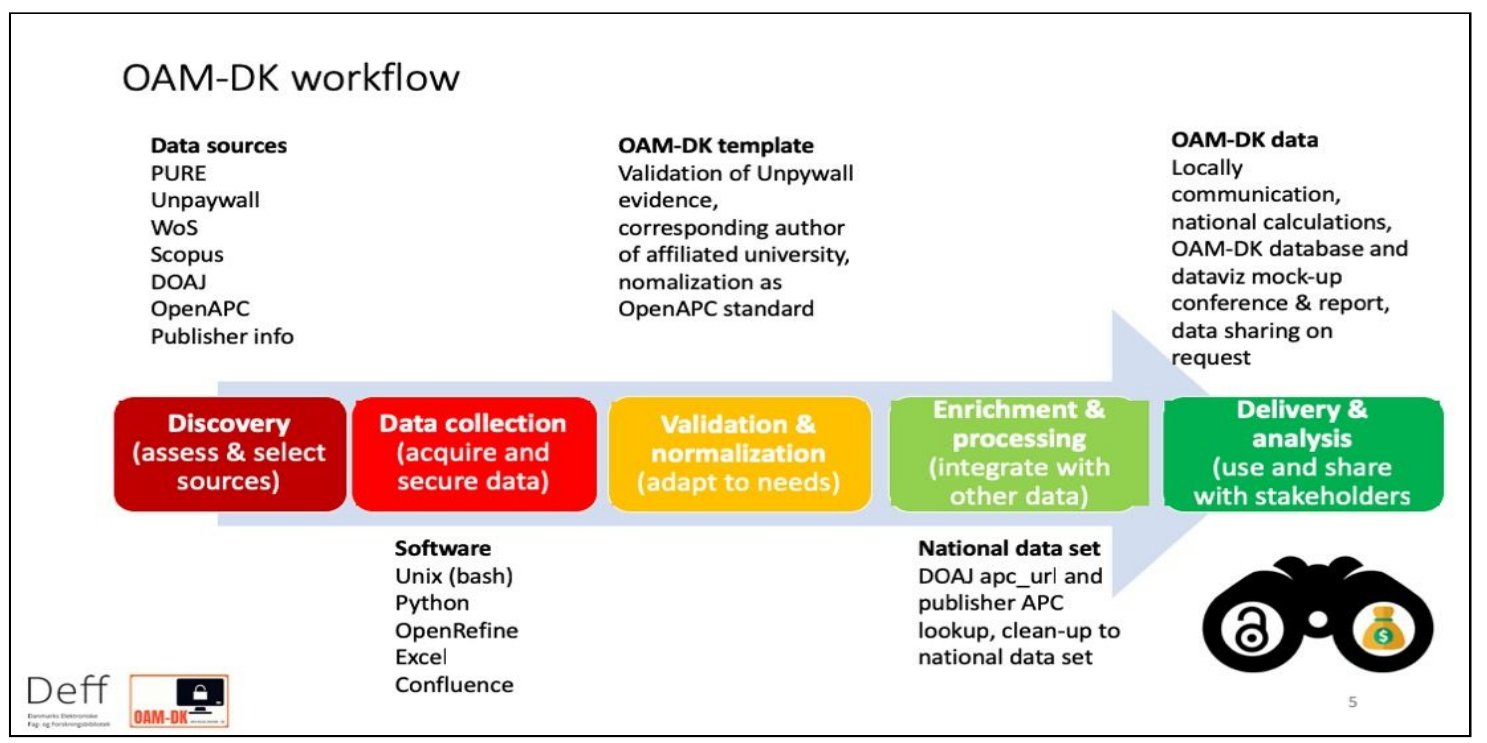

Fig. 1: Workflow proces for OAM-metoden.

Arbejdet med indsamling af 2015-publikationer i forbindelse med data fra institutionernes PURE-installationer blev aftalt og endelig godkendt forud for sommeren 2017. Metoderne til at foretage denne dataindsamling til den aftalte data-template har været forskellige fra institution til institution, idet nogle har opereret med håndholdte processer, mens andre har anvendt computationelle metoder til datafangst.

Fokus har dog været på at få ensartede data som grundlag for den nationale beregning i spor A4. Dokumentationen for den anvendte OAM-metode til indsamling af data til templaten (se Appendix 4: Open Access Monitor - guideline til dataindsamling) er resultatet af en proces, der løbende har udviklet sig i projektet sideløbende med målet om at få et nationalt datasæt i hus for 2015- og 2016-publikationer fra danske universiteter inden for projektperioden.

\section{Evaluering af metoderne for indsamling af 2015-data:}

1. Udfordringen for den igangsatte arbejdsmetode i denne case har været, at der ikke er ens procedurer for og brug af forskellige økonomisystemer hos universiteterne, hvorfor det er vanskeligt at slutte fra det specifikke til det generelle. Der hersker ingen tvivl om, at denne metode ville føre til reelle invoice data og faktura, som kan give et faktuelt overblik for universiteterne. Dog er det ikke alle faktura, der faktureres centralt i universiteterne, hvorfor 
eksternt bevilligede forsknings-output og private wildcard-betalinger fra forskeres egen lomme sjældent vil være inkluderet ${ }^{16}$.

2. Der blev efterfølgende evalueret internt i projektet på processen for dataindsamlingen til OAM-templaten samt fremgangsmåden i den foreløbige vejledning baseret på resultaterne af 2015-publikationsdata. Det blev konkluderet, at vejledningen skulle forfines og bearbejdes internt, inden arbejdet med 2016-data kunne igangsættes:

- Institutionerne skulle generere et eget datasæt med udgangspunkt i OAl fra 2015.

- Normalisering af forlagsnavne skulle selv foretages.

- Vejledningen blev forbedret med flere udførligt beskrevne arbejdsprocesser og gennemtestet af projektdeltagerne.

- To workshops blev afholdt for at klæde deltagerne på til arbejdet med 2016-data.

- En fælles liste med APC-priser blev aggregeret på de store kendte forlag, og for de mindre forlag blev der henvist til OpenAPC som autoritativ normaliseringskilde for forlags -og tidsskriftsnavne ${ }^{17}$.

Erfaringerne fra institutionerne med den første datakørsel for 2015-publikationer var, at vejledningen var mangelfuld; at det tog for lang tid; og der var desuden et generelt $\emptyset$ nske om at vende processen om, så man begynder med et stort overblik baseret på nationale publikationsdata og derefter uddeler på institutionsniveau og laver flere fælles automatiserede løsninger.

Det blev konstateret, at der er anvendt forskellige metoder for indsamling af data på institutionerne, hvorfor en national beregning for 2015 bedst kan vurderes som et testår, der som resultat giver et skævt billede.

\section{Evaluering af dataindsamling for 2016-publikationer efter OAM-DK-estimeringsmetoden:}

2016-data er indsamlet lokalt på de deltagende institutioner med fælles udgangspunkt i den udførlige vejledning (jvf. Appendix 4: Open Access Monitor - guideline til dataindsamling). Ligeledes er der produceret en anden udførlig vejledning til udførelsen af beregningerne lokalt for institutionens eget OAM-DK-datasæt (se Appendix 5: Vejledning til beregninger i OAM-projektet) . Beregningerne er ligeledes blevet udført lokalt og aggregeret på DTU, som lavede de forskellige aftalte beregninger på et nationalt niveau (Se: Afsnit: 4.1.4).

\section{Konklusioner fra databehandlingen af 2016-data:}

- Både guideline til OAM-dataindsamling og vejledningen til OAM-beregninger virker efter hensigten.

- De poster, som ikke kan køres igennem scripts, ofte på grund af manglende DOI, kan udelades, da de er tidskrævende og uden priser i mange tilfælde. Det vil sikre en højere grad af automatisering af processen

\footnotetext{
${ }^{16}$ Dette studie har unders $\emptyset$ gt forskellige typer af APC-betalinger på baggrund af 5 europæiske universiteter: Van der Graaf, M (2017): Paying for Open Access: The author's perspective, DOI: $10.5281 /$ zenodo.438037

${ }^{17}$ OpenAPC treemaps visualisation: $\underline{\text { https://treemaps.intact-project.org/apcdata/openapc/ }}$
} 
- $\quad$ APC-listepriser bør løbende høstes årligt bl.a. til overvågning af prisudvikling og analyser i forbindelse med licensforhandlinger.

- Det kan overvejes udelukkende at koncentrere sig om de store forlag, som går gennem scripts for at fokusere på særlige aftaler i et licens årshjul.

Vigtige konklusioner fra arbejdet med dataindsamlingen:

- Der er tale om at træde nyt territorium i forskningsbibliotekerne, hvilket har været en læringsproces for alle deltagere. Selvom 2016-data er langt bedre end 2015-data, er der stadig inkonsistenser i det nationale datasæt for 2016.

- Benchmark af datasæt fra 2015 og 2016 vil kræve, at 2015-datasæt bliver kørt gennem samme metode som for 2016-data. Der er blevet tilbudt overskydende timer i projektet, men flere institutioner har ikke kunnet finde ressourcerne.

- OA Monitor-data vil aldrig være 100 procent præcise, men det estimeres, at APC-udgifterne udgør ca. 20\% point af udgiften for den nationale licensportefølje, der løber op i 160 mio. kr. årligt. Heraf udgør udgiften til hybride APC'er ca. $8 \%$ point. (2016 data).

- Deling og formidling af data og resultater:

Ikke til forlagene.

Styregruppen og universiteterne beslutter med hvem, hvordan og hvornår OAM-data deles.

Der kan formidles lokalt og deles blandt universiteter, men uden fortrolige oplysninger som f.eks. licenspriser.

Drift af Open Access-monitorering vil kræve automatiserede arbejdsgange, og det anbefales pt. ikke, at der tages en endelig beslutning om en særlig løsning. I stedet har dette projekt brugt projektperioden til at indhente data og komme med anbefalinger til, hvordan metoden for dataindsamling og behandling på sigt kan automatiseres, så driften sikres (se afsnit om konsolidering af OAM-DK som mulig kravspecifikation i afsnittet, 4.1.5.1).

Videndeling af resultaterne bør og er også blevet formidlet lokalt på universiteterne til ledelsen og relevante udvalg, for hvem forskningspublicering er på dagsorden. Desuden er delresultater fra OAM-DK-data for 2015 blevet formidlet på DFFUs årsmøde i form af en poster ${ }^{18}$. Det er også besluttet i OAM-DK-styregruppen at publicere en dansksproget formidlingsartikel samt en engelsksproget international forskningsartikel, og det er blevet vurderet, at det er realistiske mål inden for projektets rammer i begyndelsen af 2019.

\subsubsection{Etablering af workflow (best practice) på tværs af projektets deltagende institutioner (A.3).}

Formålet med sporet er at få etableret et ensartet workflow (best practice) til identifikation af de forskningsartikler, som de enkelte forskere på universiteterne har publiceret enten som hybrid eller gylden OA.

Med baggrund i de tre fremgangsmåder, som er praktiseret i spor A.2:

- Indhentning af invoice data fra økonomiafdelinger

\footnotetext{
${ }^{18}$ Svendsen, M., Hansen, L. A. J., \& Andersen, D. (2017). Open Access Monitor - DK: Case: University of Copenhagen, 2015 data. https://doi.org/10.5281/zenodo.896132
} 
- Manuelle opslag pr. artikel

- Identifikation af data via scripts

blev det i OAM-DK gruppen samlet besluttet at gå efter metoden: Identifikation af data via scripts for indsamling af 2016-data. Der var en intern diskussion i projektet om, hvorvidt der skulle nedsættes en arbejdsgruppe, som skulle håndtere en fælles indsamling og bearbejdning af data for alle universiteter, eller om det skulle være de enkelte universitetsbiblioteker, som selv skulle forestå arbejdet. Der var en klar udmelding fra de enkelte universitetsbiblioteker om, at de selv $\emptyset$ nskede at kunne fremskaffe og bearbejde data.

Den valgte metode: identifikation af data via scripts, satte en række krav til udførelsen, så et ensartet arbejdsgrundlag i fremfinding og bearbejdning af data blev sikret.

Første skridt på vejen var udarbejdelsen af en Cookbook $^{19}$ med opskrifter til indhentning af data via scripts fra de vigtigste datakilders API'er (Web-of Science/Clarivate, Scopus/Elsevier og Unpaywal samt DOAJ).

I tillæg til kogebogen blev der afholdt en workshop på Det Kongelige Bibliotek i begyndelsen af 2018. Her blev der ydet hjælp til installering af programmer, demo af workflow med mulighed for at arbejde på egne data samt en introduktion til normalisering og beregning af data (se Appendix 1).

Der var en pæn deltagelse på 25 personer fra alle universitetsbiblioteker samt DEFF. Workshoppen blev efterfølgende evalueret overvejende positivt ift. kogebogens anvendelighed. Dog herskede der mere usikkerhed om færdighederne til at kunne gennemføre indsamlingen efter metoden i egen institution.


Fig. 2: Evaluering fra workshoppen af egnethed og læring ift. OAM kogebog.

Andet skridt på vejen var den endelige udarbejdelse af en vejledning, som indeholder den fulde arbejdsproces med indhentning af data og den videre bearbejdning af data, så det enkelte universitet til sidst har kunnet skabe et overblik over, hvilke artikler der er blevet publiceret som gylden eller hybrid OA og til hvilken pris.

I tillæg til vejledningen blev der holdt en opfølgende workshop på CBS d. 3. maj. Workshoppen var

${ }^{19}$ https://github.com/enemydown-dk/oam dk workshop/blob/master/cookbook.md 
denne gang begrænset til deltagere fra OAM-DK, som mødte op med udtræk af data fra de enkelte institutioner. Workshoppen havde fokus på den efterfølgende bearbejdning af dataudtrækkene.

Som overordnet sikring af ens data universiteterne imellem blev der udarbejdet:

- En standardiseret data template til registrering af data omkring den enkelte forskningsartikel gældende pr. universitet.

- Normalisering af forlags navne og tidsskriftstitler.

- Priser på APC betaling fra de enkelte forlag (hvis oplysning om betaling fra forsker/forlag ikke haves).

- Kursfastsættelse.

\section{Diskussion af resultater:}

At arbejde med data via scripts er en udfordring og det kræver tekniske it-kompetencer. Der er fortsat en del arbejde, som må gøres manuelt. Dette arbejde er tidskrævende, og man kommer lettest omkring det ved at have kendskab til OA-publiceringens kompleksitet.

Det er udfordrende at arbejde med forskningsartikler som er 2 år gamle. Udfordringen består i, at tidsskrifter i den periode kan være skiftet fra licens til OA og vice versa. Dette kan have indflydelse på de aktuelle metadata, der hentes via scripts.

Forskningsartikler fra konferencer samt mindre forlag er mere udfordrende at identificere på corresponding author og OA-type, da de ofte ikke er indekseret i WoS eller Scopus. Det kan overvejes, om OA-monitorering for fremtiden bør begrænses til kun at omhandle forlag, hvor der finder en højere publiceringsaktivitet sted.

Fremgangsmåden med identifikation af data via scripts har dog sikret, at der for 2016 data er et ensartet og markant forbedret overblik for, hvor stor en publiceringsaktivitet der har været på hvert enkelt universitet inden for gylden og hybrid OA sammenlignet med 2015 data (se spor A.4).

Rådata fra de enkelte universiteter ligger på OAM-DK-projektets site på samarbejdsplatformen Confluence. Da der på de enkelte universiteter er et ønske om at kende resultatet, som unders $\varnothing$ gelsen har frembragt, har flere deltagere internt orienteret enten ledelsen eller på fakultetsniveau.

\section{Opsamlende konklusioner:}

Identifikation af data via scripts kan anbefales som en best practice. Det sikrer en hurtigere og mere effektiv arbejdsgang, end hvis alle artikler skulle slås op enkeltvis, selvom der fortsat er en del manuelt arbejde, som ikke bør underkendes.

Det er muligt at videreudvikle metoden, så alle scripts bliver samlet til én kørsel med indbyggede logiske strukturer for at validere typen af OA. Dette vil lette den tekniske side af arbejdet samt minimere valideringen og usikkerheden, der kan opstå heraf. Det vil endvidere være værd at unders $\varnothing$ ge, om nye lancerede OA-giga-indekser som Dimensions ${ }^{20}$ eller 1 Findr ${ }^{21}$ vil kunne supplere eller afløse de kilder, som OAM-metoden g $\varnothing$ r brug af nu, og om de vil kunne tilføje flere oplysninger til datasættene. Fremsøgning af Open Access er et dynamisk felt med mange nyudviklinger, hvorfor

\footnotetext{
${ }^{20}$ https://www.dimensions.ai/

${ }^{21} \mathrm{https://www.1science.com/1findr/}$
} 
workflows og metoder til identifikation løbende bør tages op til revision.

\subsubsection{Beregning på omfang af gylden og hybrid OA samt afledte APC udgifter (A.4)}

Formålet med spor A.4 er at levere både en institutionel og national og beregning på omfang af gylden og hybrid OA-publicering samt de afledte udgifter (apc).

Første år, som blev gennemgået, var publikationer fra publikationsåret 2015. Efterfølgende blev beregningerne også gennemført med publikationer fra publikationsåret 2016.

Beregninger, som projektet ønskede at lave, har været fokuseret:

Per universitet

Optællinger per universitet:

- Antal artikel publiceringer i alt*

- Antal artikelpubliceringer, hvor universitetet er corresponding author

- Antal artikelpubliceringer fordelt på type (**grøn, gylden, hybrid, **ikke OA andel i antal og procent)

* Forudsætter at der ikke er slettet $i$ antal publikationer (der er det samme antal publikationer i det regneark som er modtaget og i det som afleveres)

**Grøn OA og ikke OA er nok interessante om perspektivet er OA, men mindre i økonomisk sammenhæng, da det er vanskeligt at beregne udgifter til grøn OA. De er ikke obligatoriske så oplysningerne er ikke udfyldt i alle ark.

$\varnothing$ konomi per universitet:

- Samlet udgifter til publicering (både i Eur og DKK)

- Udgifter til publicering fordelt på gylden og hybrid (både i Eur og DKK)

- Gennemsnitspris per publicering (gylden og hybrid) og variation i pris (både i Eur og DKK)

- Top 10 forlag $\varnothing$ konomisk set -gylden

- Top 10 forlag $\varnothing$ konomisk set -hybrid

Nationalt*

*Optællinger nationalt giver kun mening hvis alle publiceringer for alle universiteter er gennemgået.

Optællinger nationalt:

- Antal artikel publiceringer i alt (dubletter fjernes med doi)

- Antal artikelpubliceringer hvor danske universiteter er corresponding author

- Antal artikelpubliceringer fordelt på type (**grøn, gylden, hybrid, **ikke OA (andel i antal og procent)) 
Der foreligger dermed baseret på OAM-DK projektets estimeringsmodel en samlet beregning på APC-udgifter for de enkelte institutioner samt et nationalt overblik for danske universiteter (se Appendix 9: OAM beregninger 2016).

Diskussion af opståede udfordringer:

2015-publikationer:

Beregningerne per institution blev for publikationsåret 2015 udarbejdet af DTU Bibliotek. P.g.a. uensartethed i databehandlingen (i spor A.2) fra de enkelte institutioner var det ikke muligt at lave de nationale optællinger og beregninger for 2015. Den uensartede databehandling var også en vigtig grund til, at gruppen aftalte, at data for 2015 ikke bør offentliggøres.

2016-publikationer:

Efterfølgende er der udarbejdet en vejledning for databehandling, og alle institutioner skal selv - ud fra den beskrevne vejledning - lave universitetets beregninger. Den endelige vejledning blev aftestet af et par deltagere i foråret 2018.

Beregningerne for 2016 er udarbejdet af den enkelte institution. Der hersker enighed om, at både 2015 og 2016 fortsat er præget af børnesygdomme, og at en sammenligning af de to år vil kræve, at 2015 for nogle universiteter bliver genkørt efter samme metode som 2016.

Anbefalinger på baggrund af resultater:

2015-data:

- Vi skal forstå resultaterne bedre

- Ensartet fremgangsmåde næste gang

- Ensartet kvalitetskontrol næste gang

- Det skal afklares, hvad der er den bedste fremgangsmåde. Ønskes der et så præcist overblik som muligt over omkostninger til APC, eller hvad er målet?

- Det blev besluttet, at 2015-beregningerne er et test år, der handlede om at få metoden på plads og blive sikre på, hvilken metode er den bedste.

2016-data:

- Manuelle behandlinger betyder udfordringer og forskellige beslutninger, der påvirker beregningerne ( $\mathrm{fx}$. hybrid eller gold, APC eller ej, normaliseret eller ej).

- Det kræver indgående OA know-how at lave de manuelle behandlinger

- Normalisering af forlagsnavne og tidsskrifttitler skal være bedre (evt. centralt arbejde)

Både spor A.2 og A.3 danner grundlaget for arbejdet i A4, og udfordringer i disse to spor vil også være synlige i spor A.4.

Opsummerende konklusioner for:

2015-data: 
- Der er anvendt forskellige metoder blandt institutionerne, hvorfor der ikke meningsfuldt kan sammenlignes på tværs

- Data på gylden OA passer ikke med OAI gylden

- DOAJ er ikke altid dækkende ift. identificering af gyldne tidsskrifter (som ex. rykker DTU fra 362 til $682=320$ flere gyldne artikler/xx procent!)

2016-data:

- Individuelle vurderinger gør beregningerne usikre

- Manglende normaliseringer gør beregningerne usikre

- Manglende APC-priser på tidsskrifter, som andre har APC på, gør beregningerne usikre.

Videndeling og offentliggørelse af de nationale beregninger er udfordret af det politiske landskab. Danske universiteter har for et par år siden responderet til licenskonsortiet under DEFF, at de ikke $\emptyset$ nsker APC som en del af licensforhandlingerne og at de specifikke APC-tal i OAM-projektet tilhører universiteterne.

Projektet har siden diskuteret, at det heller ikke nødvendigvis er en god ide at offentliggøre tal fra OAM-projektet i hverken OA Indikatoren eller andre steder, da forlagene vil få et overblik over, hvor mange penge der er i det danske system til APC for gyldne og hybride artikler.

\subsubsection{Implementering af databeregninger i infrastruktur samt udstilling/visualisering i OA indikator (A.5)}

Aktiviteten på dette arbejdsspor var i udgangspunktet tiltænkt et muligt samarbejde om at få potentielle data af interesse udstillet og/eller integreret med den danske Open Access Indikator, der monitorerer den danske Open Access-strategi og universiteternes performance på vegne af UFM (Uddannelses -og Forskningsministeriet). Dialogen og afs $\varnothing$ gningen af denne mulighed forud for og undervejs i projektet har dog været begrænset.

I stedet er det primært blevet prioriteret af projektledelsen i samarbejde med styregruppen at få udarbejdet en mulig ramme hen imod en egentlig proof-of-concept for en Open Access Monitor-database med et simpelt dashboard interface for interesserede institutioner. Det skal nævnes, at dette arbejde fortsat er under udvikling, og det er planlagt at skulle indgå i en ansøgning til DEFF som et konsolideringsprojekt næste år.

\subsubsection{Udkast til specifikation og mock-up: OA Monitor}

Data importeres fra API'er, strukturerede csv-filer eller andre datakilder direkte ind i PostgreSQL, hvor data kan organiseres i meningsfulde tabeller.

Data kan bearbejdes med det strukturerede sprog SQL, hvorefter udtræk er muligt til 3. parts-programmer til visualisering, der kan installeres lokalt efter behov. Som eksempler kan nævnes:

- Falcon SQL (https://plot.ly/free-sql-client-download/), der er en gratis og licensfri SQL-klient med in-line datavisualisering, der er udviklet af plot.ly (se nedenfor)

- Plotly (https://plot.ly/), der er et open source webbaseret visualiseringsmiljø for data 
- Tableau (https://www.tableau.com/), enterprise-løsning med avanceret platform for BI- og datavisualisering.

- Excel: data kan også hentes til og visualiseres i Excel

Goal

(B)estimate for paid OA / DKK

Data foundation

PURE 2015-2016 publication data

OA data sources (API)

Unpaywall (prev. OAdoi)

DOAJ

Web of Science

Scopus + Science Direct

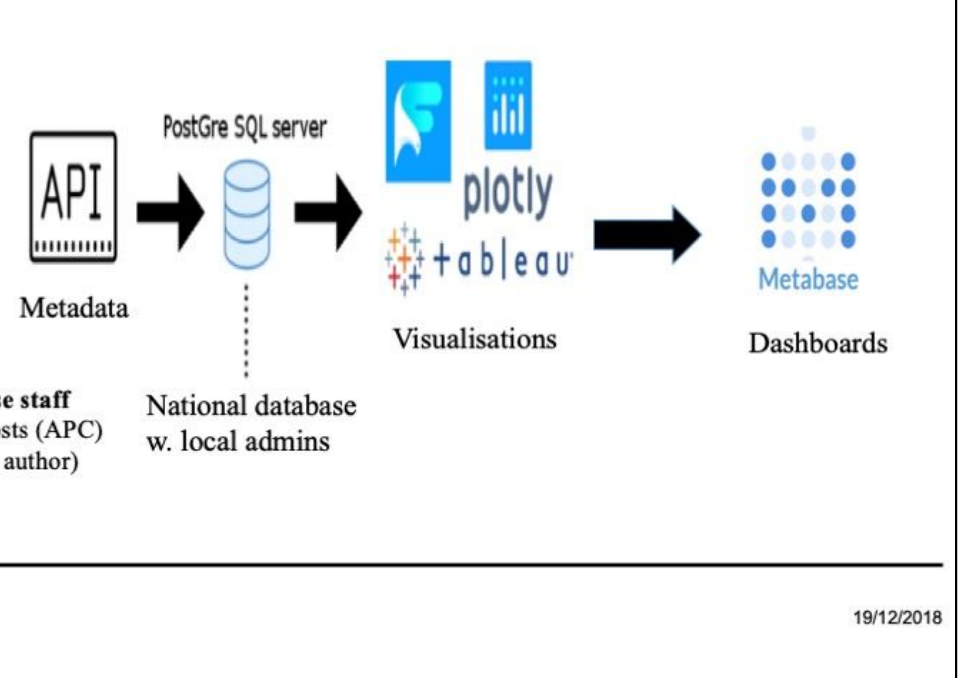

Data evidence for management \& license staff

No. of gold + hybrid articles + derived costs (APC)
Distribution pr. institution (corresponding author)

Publisher list prices

(1)

Fig. 3: OA Monitor software komponenter

PostgreSQL (www.postgresql.org) er en fri objekt-relationel database server, udgivet under en fleksibel BSD-licens. Den er et alternativ til andre open-source databasesystemer (f.eks. MySQL), ligeså til de proprietære systemer (f.eks. Oracle eller Microsoft SQL Server).

I stil med andre open-source-projekter er PostgreSQL ikke kontrolleret af et enkelt firma, men er afhængig af et globalt netværk af udviklere og firmaer, som bistår med udvikling. PostgreSQL fås til en lang række operativsystemer, heriblandt Linux og Windows.

Projektet anbefaler, at systemet installeres på en Linux-server, da kompetencerne i projektet med driften ligger her. Desuden benytter en stor del af kerneudviklerne Linux som udviklingsplatform, hvormed udviklingsversionen ikke altid er garanteret funktionel på andre operativsystemer. Skal serveren virtualiseres, er det oftest også billigere at virtualisere på Linux kontra Windows. Fra et brugersynspunkt er forskellen dog ikke eksisterende, og begge host-systemer kan løse opgaven.

Herunder ses systemkrav for tre forskellige systemvariationer: En minimal, en anbefalet lokal løsning og en cloud-baseret løsning. Alle løsninger kræver nok diskplads til at kunne indeholde datamængden i databasen, ligesom der skal planlægges udvidelse af hukommelse/processorkraft ift. antal brugere.

\section{Minimum systemkrav i produktion}

64 bit CPU

64 bit Operativsystem

2 Gigabyte hukommelse

Dual Core CPU (2x)

RAID 1 (Spejling)

\section{Anbefalet systemkrav i produktion (hosting)}


64 bit CPU

64 bit Operativsystem

32 Gigabyte hukommelse

Quad Core CPU (4x)

RAID 1 eller $10(1+0)$

\section{Anbefalet systemkrav i produktion (cloud)}

64 bit CPU

64 bit Operativsystem

32 Gigabyte hukommelse

Quad Core CPU (4x)

Backup plan hos cloud-partner

\section{Priseksempler:}

Amazon Web Services (AWS):

Navn: t2.xlarge

Virtuelle CPU'er: 4

Ram: $16.0 \mathrm{~GB}$

Brug: $100 \%$

Pris pr. Måned: \$ 154.60 992 DKK.

\section{Digital Ocean:}

Virtuelle CPU'er: 8

Ram: $32.0 \mathrm{~GB}$

Diskplads: $640 \mathrm{~GB}$

Månedlig Transfer MAX GB: 7 TB

Pris pr. måned: \$ 160 1024 DKK.

Der findes flere udbydere, og der findes både større og mindre pakker fra alle leverandører. Det er vigtigt at bemærke, at enkelte Iøsninger som Digital Ocean sætter et max. på månedlig overførsler ligesom AWS vil være billigere, såfremt der ikke opnås 100\% udnyttelse. Hos Digital Ocean betaler man altid det samme. Projektet anbefaler AWS, da vi har erfaring med dem som en stabil cloud-partner.

\section{Tilvalgsydelser:}

Metabase: https://www.metabase.com/

Metabase er den nemme, open source-måde for alle til at stille spørgsmål til og lære af data. Via filtrering og gruppéring af data er det enkelt at finde, hvad man leder efter, alt uden at skulle skrive en linje af sql eller at skulle have hjælp af en kollega. Metabase giver nem mulighed for grafisk repræsentation af data til grafer og diagrammer med et par få klik.

Ønsker man at grave ind i komplicerede ting, giver Metabase en ret elegant SQL-grænseflade til dem, der har brug for lidt mere indsigt. Metabase kan implementeres i forlængelse af PostgreSQL, og giver muligheden for at oprette interaktive dashboards som videreformidler data i form af kurver og grafer. 
Pris: Med udgangspunkt i den mindste serverinstans fra AWS vurderes prisen for en instans af MetaBase i forlængelse af Postgresql installationen at beløbe sig til \$20.0 130 DKK.

OAM-DK projektet anbefaler en cloud-baseret løsning, da det vil være enkelt at op- og nedjustere ram, processor kraft og diskplads ift. de aktuelle behov - ligesom data backup $\mathrm{mm}$. kan aftales med cloud-partneren (f.eks. Amazon Web Services AWS, https://aws.amazon.com/).

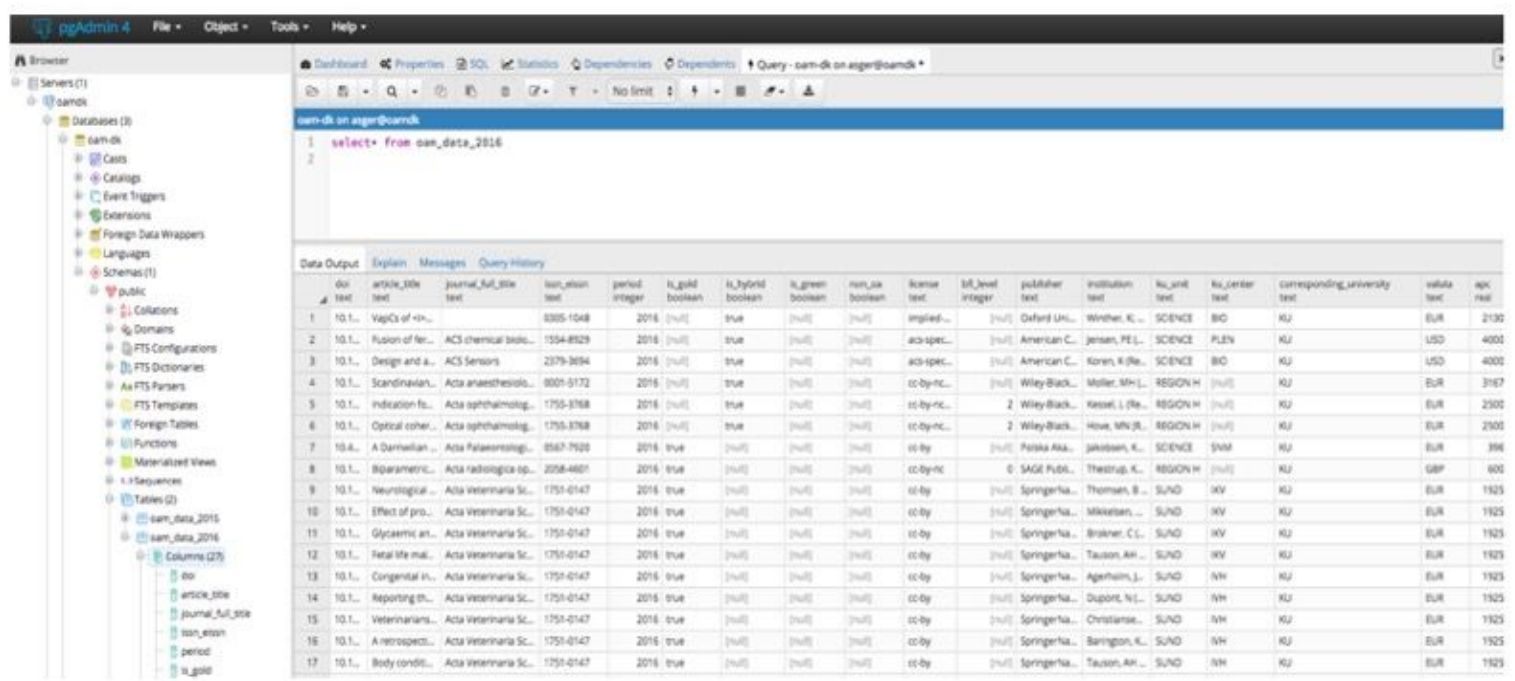

Fig.4: PostgreSQL interface, ex. på strukturering af OAM 2016 data.

Data kan selekteres efter behov via sql og kan udstilles i en hurtig preview visualisering i Falcon SQLclient:



Fig. 5: Sql query i Falcon for hybrid APC. 


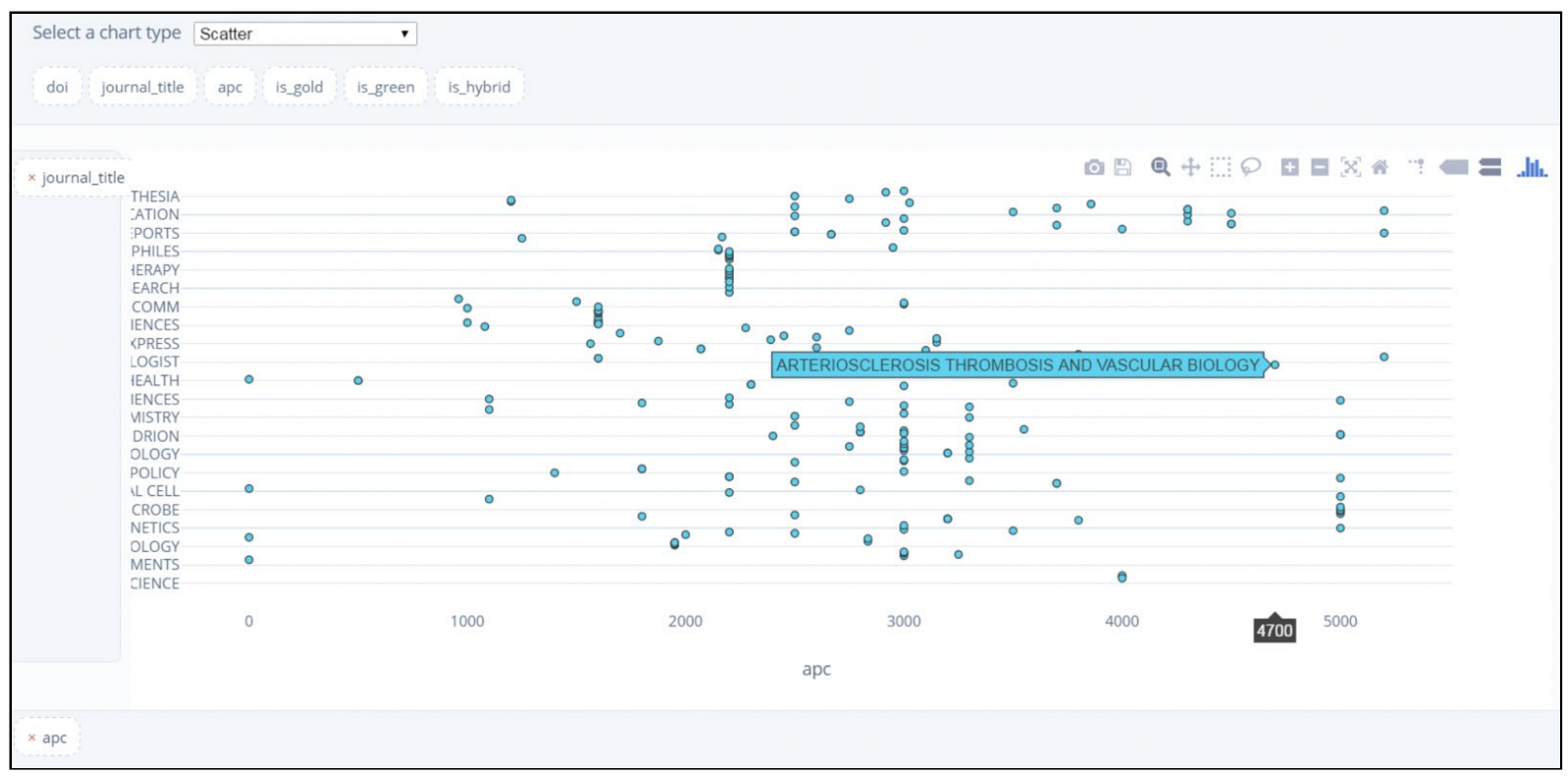

Fig. 6: Ex. på scatterplot for hybride APC i USD, (Københavns Universitet, 2015)

For mere avancerede analyser kan efterbehandling af data foretages i fx plot.ly, hvis der $\varnothing$ nskes charts fra statistik eller bibliometri.



Fig. 7: Ex. på boxplot for gold og hybrid APC i USD, (Københavns Universitet, 2015).

Endelig kan data også trækkes fra PostgreSQL til Excel via interfacet i Excel. Visualisering af data kan ligeledes foregå i dette miljø. 


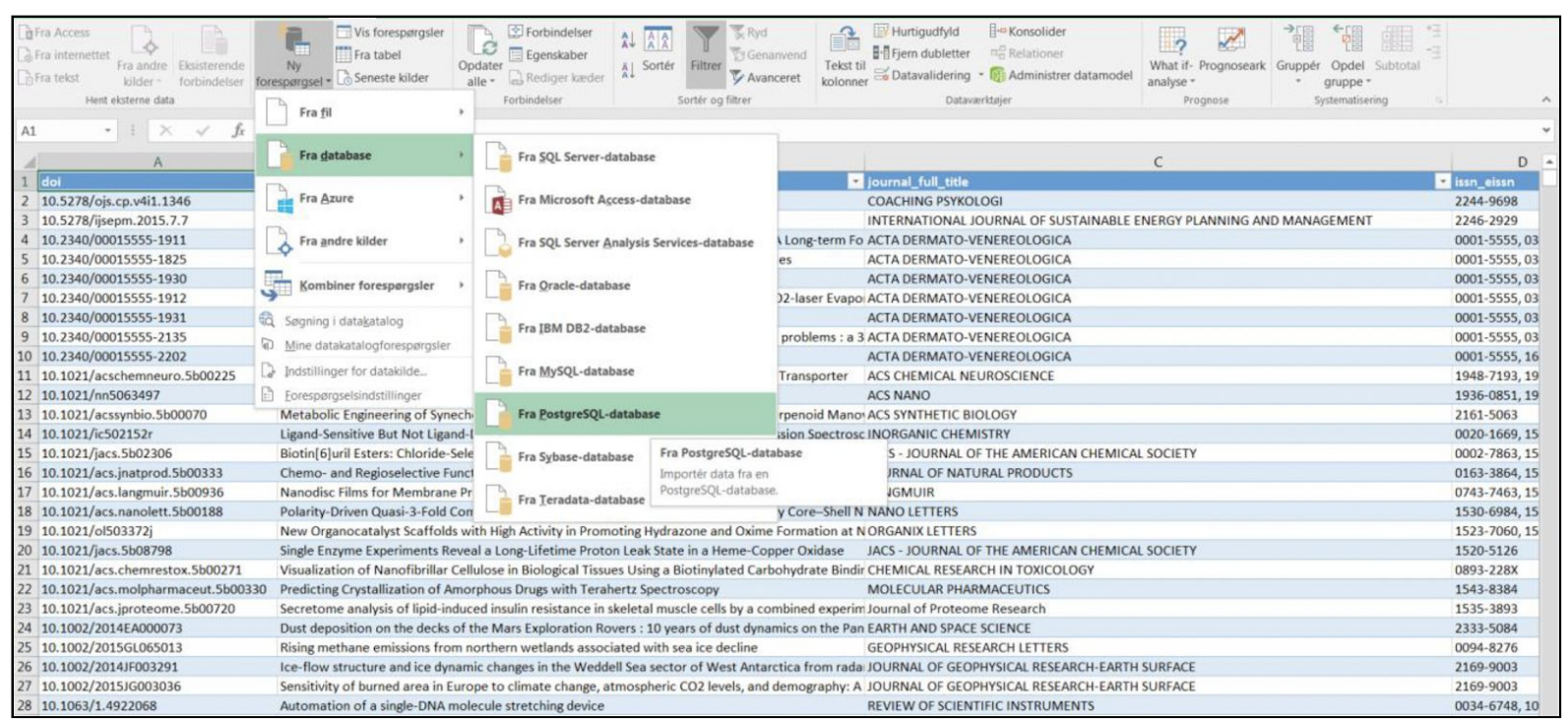

Fig. 8: Excel interface for dataimport fra PostgreSQL.

OAM-data kan udstilles i Metabase som visualiserede dashboards, som brugere som fx. licensforvaltninger, ledelse og forskere kan få adgang til som en webservice. Data kan også integreres som add-on til andre services, hvor metadata ønskes udstillet.

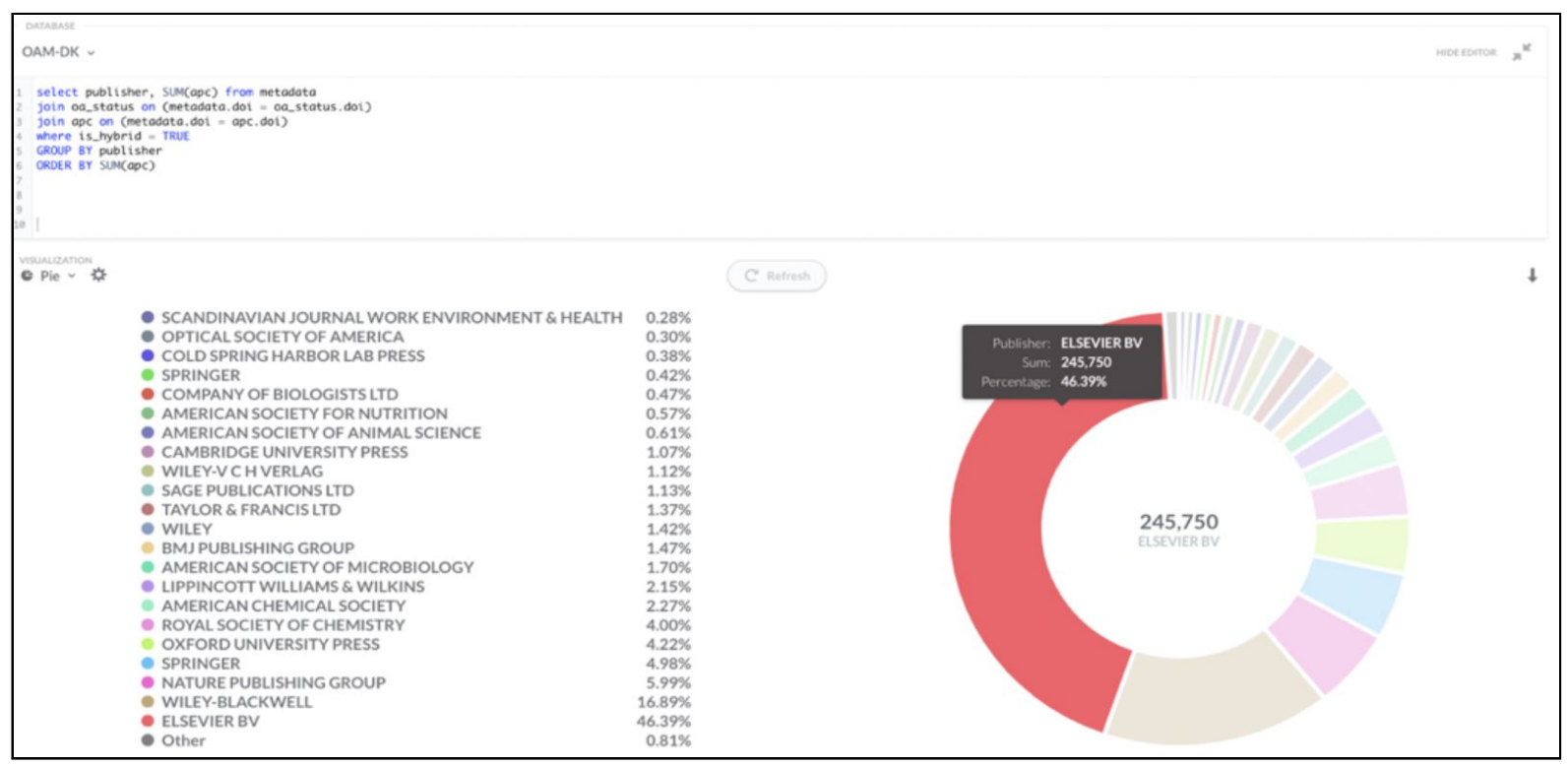

Fig. 9: Metabase - APC dashboard: udgivers (\%) andel af hybride APC. 


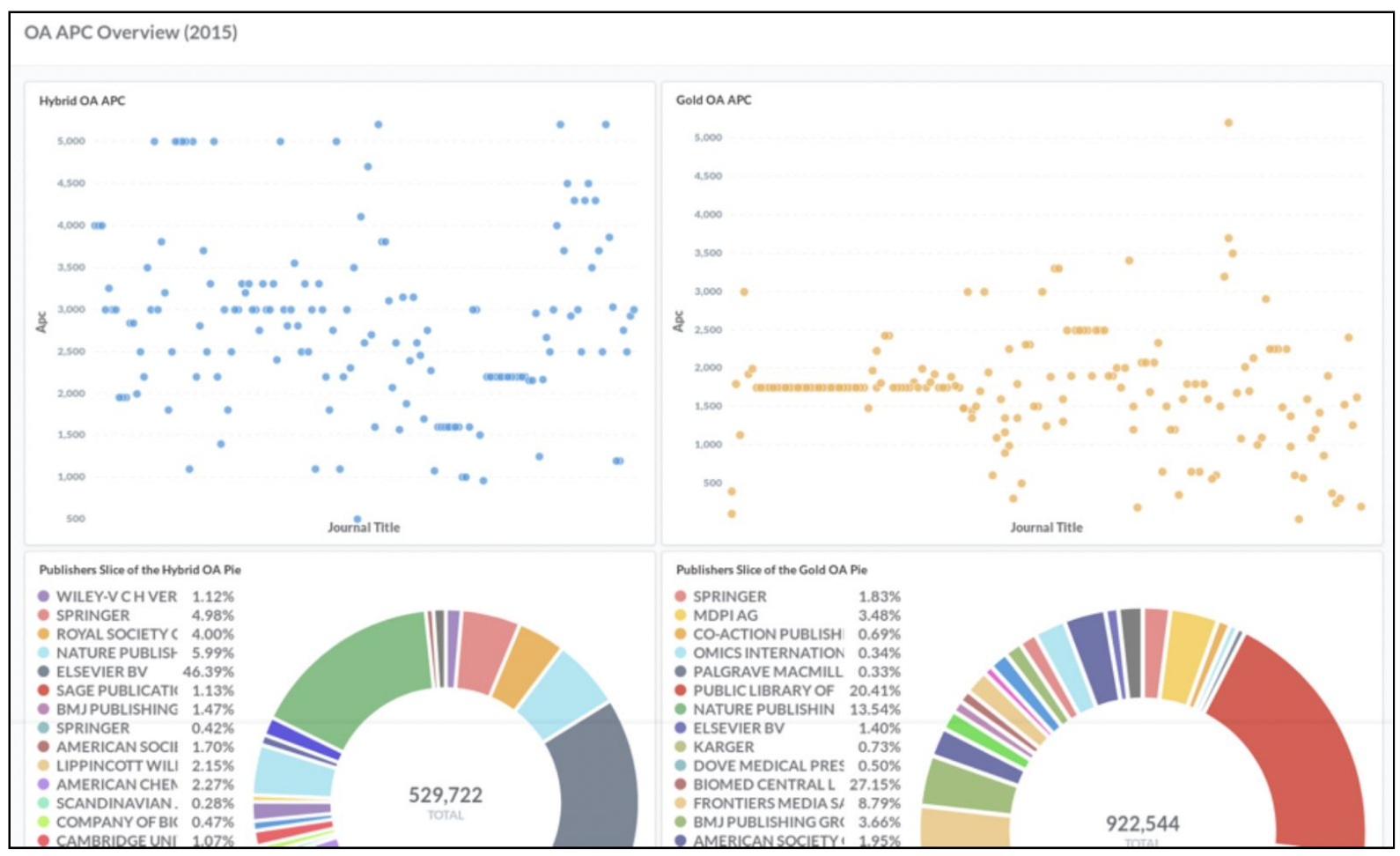

Fig. 10: Metabase - APC dashboard: udgivers andel (\%) af hybride og gold APC.

Det er blevet anbefalet fra projektets styregruppe, at det sikres, at OAM-data ikke ender som en torso af data, der ikke kan integreres med andre data-points i det nuværende systemlandskab, som universiteterne gør brug af. Det skal derfor nøje undersøges, hvordan OAM-data kan tænkes ind og om muligt integreres med de allerede eksisterende og relaterede systemkomponenter og services, der anvendes i det danske økosystem (se Appendix 6).

Hovedkonklusionen for de forskellige systemer, der monitorerer Open Access, er, at de stadig er for præmature eller bygger på data, som endnu ikke er tilgængelige og måske heller ikke bliver det (se afsnit 4.2.3.2). Derimod er aggregering af data til en database, hvor (egne) omend estimerede publikationsdata kan trækkes ud og anvendes i forskellige sammenhænge, langt mere brugbare på nuværende tidspunkt.

Det anbefales derfor, at der udarbejdes en applikation, som automatiseret kan samkøre scripts, der henter 3. parts data og validerer disse ud fra en automatiseret beslutningsstruktur, som leverer metadata ind i en database, som herefter kan udstilles i et mere simpelt grafisk interface. Dette vil yderligere $\varnothing$ ge brugervenligheden som eksempelvis i dashboard-løsninger til forskellige interessenter.

\subsubsection{Involvering af eksterne partnere (A.6)}

OAM-DK har forud for projektbevillingen og også undervejs løbende haft en tæt kontakt med internationale partnere og andre nationale projekter, der har lignende aktiviteter for monitorering af Open Access og afledte udgifter på dagsordenen.

Særligt samarbejdet via DEFF i Knowledge Exchange har været en vigtig grundsten i fors $\varnothing$ get på at opsamle og udvikle krav og anbefalinger til OA monitorering, der som nævnt er beskrevet $\mathrm{i}$ 
rapporten:

- Knowledge Exchange consensus on monitoring Open Access publications and cost data fra den internationale workshop afholdt i København. Rapporten har også været præsenteret på konferencen LIBER ${ }^{22}$ og i OpenAire 23 i 2017.

Desuden har projektdeltagere fra OAM-DK deltaget i nordisk samarbejde om OA monitorering via:

- Joint Nordic Meeting on Open Access \& Licensing, 15.-16. juni, 2017, i Stockholm ${ }^{24}$

- LOA2018 - Licenser \& Open Access, 1. juni, 2018, i Stockholm²5. Se desuden den OAM-DK producerede rapport (Appendix 10: Rapport: LOA2018 (Licens \& Open Access).

samt internationalt samarbejde om standarder for APC-markedet via:

- 3rd ESAC Workshop 2018: On the Effectiveness of APCs, 28.-29. juni, München, hvor der også blev leveret input til en rapport fra OAM-DK ${ }^{26}$.

Endelig har OAM-DK projektet selv været løbende i kontakt med lignende projekter i Tyskland, UK, og Sverige samt vært for en workshop (se Appendix 1: OAM workshops - program) med international repræsentation og oplæg om forskellige Iøsninger til OA monitorering, som der kan læses mere detaljeret om i afsnit 4.2.3.2.

\subsection{Fase B:}

\section{Identifikation og udvikling af best practice for APC-administration}

Fase B: Identifikation og udvikling af best practice for APC-administration

Fase B struktureres omkring 3 arbejdsspor, der vil unders $\varnothing$ ge, identificere og udvikle en best practice for universiteternes APC-administration.

1. Afdække nuværende lokale praksis på universiteterne.

2. Undersøgelse af central apc-administration, invoice-systemer, udenlandske erfaringer $\mathrm{mm}$.

3. Udvikle anbefaling til national best practice på baggrund af institutionernes behov.

\footnotetext{
${ }^{22}$ Svendsen, M., \& H. Thomasen, C. (2017). Knowledge Exchange Consensus: Monitoring of Open Access Publications and Cost Data. Abstract from The 46th LIBER Annual Conference, Patras, Greece: http://liber2017.library.upatras.gr/programme/

${ }^{23}$ OpenAIRE - Impact and Measurement of Open Access, HiOA, Oslo (14.2.2017): https://www.openaire.eu/openaire-workshop-impact og https://www.youtube.com/watch?v=5gAniqCvAcg

${ }^{24}$ https://openaccess.blogg.kb.se/event/ioint-nordic-meeting-on-open-access-and-licensing/

25 https://openaccess.blogg.kb.se/2018/02/15/loa-2018-licenser-open-access/

${ }^{26}$ http://esac-initiative.org/activities/3rd-esac-workshop-munich-28-29-june-2018/
} 


\subsubsection{Afdække nuværende lokale praksis på universiteterne (B.1)}

Formålet med spor B.1 var at få identificeret, om der på de danske universiteter eksisterer en praksis for at kontere særlige publikationsbaserede udgifter inkl. bl.a. APC-betalinger til Open Access. Nogle danske universitetsbiblioteker har allerede oprettet en kontostreng til Open Access og andre relaterede publikationsudgifter, men i hvilket omfang, der findes konti til registrering af APC-betalinger og hvorvidt de bliver brugt, er endnu ikke blevet afdækket.

I forbindelse med projektets opstart blev det i sporet besluttet at designe en række spørgsmål via Surveyxact til en st $\varnothing$ rre spørgeskemaunders $\emptyset$ gelse, som blev sendt ud til de centrale $\varnothing$ konomisektioner lokalt på universiteterne, hvor der er ansat controllere (se Appendix 7).

- Hvilket universitet er du tilknyttet?

- Hvilken afdeling/enhed svarer du på vegne af?

- Har jeres afdeling/enhed retningslinjer for, hvor publiceringsomkostninger (fx. colour charges, page charges, Open Access (også kaldet APC) og tabeller/grafik) skal konteres?

- Laver jeres afdeling/enhed kvalitetskontrol af, om institutterne har konteret publiceringsomkostninger korrekt?

Desuden blev sendt et spørgeskema ud til udvalgte institutter på universiteterne (se Appendix 8), hvor der var identificeret en $h \varnothing j$ volumen af OA-publicering:

- Hvilket institut svarer du på vegne af?

- Betaler din enhed for en eller flere af nedenstående publiceringsomkostninger?

- Er der fælles retningslinjer for, hvor I konterer publiceringsomkostninger? - Ja (beskriv venligst retningslinjerne)

- Har dit universitet en kontostreng til Open Access betaling? - Ja (Hvilken?)

- Kan du oplyse, hvor meget din enhed har brugt på publiceringsomkostninger i 2015? - Ja, hvor meget (ca. beløb i DKK), - hvis ja, heraf til Open Access/APC (ca. beløb i DKK)

Målet med delsporet var at få afklaret økonomisektionernes interne arbejdsprocesser i forbindelse med betaling af APC. Herunder om man var opmærksomme på eventuelle kontostrenge.

Udfordringen med spørgeskemaer er at ramme den rigtige modtager samt formulere spørgsmålene i et sprog, der giver mening hos modtageren, der ikke har særlig viden på området.

Diskussion af resultater:

Spørgeskemaet blev lidt for indforstået, og det lykkedes ikke at nå de helt rigtige modtagere alle vegne. Men det overordnede resultat forbliver klart, nemlig at der eksisterer et manglende kendskab til Open Access området og også til de kontostrenge, der evt. er oprettet til formålet.

På centralt niveau er der ikke en praksis for at skelne synderligt til videnskabelig publicering, hvor 
faktura som oftest følger den almindelige finanskontoplan. Det blev anbefalet fra projektet, at resultaterne fra spørgeskemaunders $\varnothing$ gelsen bliver taget til efterretning lokalt på universiteterne.

Der er lavet en rapport på baggrund af resultaterne i Surveyxact (se opsamling i afsnit 4.2.3.1).

\subsubsection{Undersøgelse af central apc-administration, invoice systemer samt udenlandske erfaringer (B.2)}

Som indledning til dette arbejdsspor blev der arrangeret og afholdt en international workshop for at afdække allerede eksisterende systemers anvendelighed for monitorering, som refereret $i$ afsnit 4.1.6 og grundigere beskrevet $\mathrm{i}$ afsnit 4.2.3.2.

Resultatet af workshoppen, der havde til formål at undersøge og internt evaluere de præsenterede Iøsninger til OA monitorering, ses i oversigtsform nedenfor. Skemaet giver et overblik over forskellige løsninger til APC-monitorering, der allerede er taget i brug og beskriver dem ud fra flg. parametre:

- Løsning/produktnavn

- Udbyder/ansvarlig

- Målgruppe/Interessenter

- IT-system/platform

- Ressourceforbrug

- Finansiering

- Bemærkninger 


\begin{tabular}{|c|c|c|c|c|c|c|c|}
\hline $\begin{array}{l}\text { Løsning / } \\
\text { produktnavn }\end{array}$ & $\begin{array}{l}\text { Udbyder/ } \\
\text { ansvarlig }\end{array}$ & Mălgruppe/interessenter & Formål & IT-system & Ressourceforbrug & Finansiering & Bemærkninger \\
\hline $\begin{array}{l}\text { JISC Monitor } \\
\text { Local }\end{array}$ & $\begin{array}{l}\text { JISC } \\
\text { Collections } \\
\text { (England) }\end{array}$ & $\begin{array}{l}\text { Udviklet til engelske } \\
\text { universitetsbiblioteker } \\
\text { Interessenter er bevillingsgivere, } \\
\text { universiteter, politikere }\end{array}$ & $\begin{array}{l}\text { Afrapportering } \\
\text { og check af } \\
\text { compliance til } \\
\text { (engelske) } \\
\text { bevillingsgivere } \\
\text { monitorerer } \\
\text { APC udgifter }\end{array}$ & $\begin{array}{l}\text { Database, } \\
\text { webservice }\end{array}$ & $\begin{array}{l}\text { Manuel inddatering af } \\
\text { invoice data fra forsker } \\
\text { eller } \varnothing \text { konomisystemer } \\
\text { af administrative } \\
\text { medarbejdere }\end{array}$ & $\begin{array}{l}\text { Abonnement } \\
\text { samt udgifter til } \\
\text { personale }\end{array}$ & $\begin{array}{l}\text { Skræddersyet UK Iøsning } \\
\text { kræver umiddelbart meget } \\
\text { tilretning } \\
\text { Institution ejer data } \\
\text { Integration med national } \\
\text { service JISC Monitor }\end{array}$ \\
\hline OpenAPC & $\begin{array}{l}\text { Bielefeld } \\
\text { University } \\
\text { Library for } \\
\text { (Tyskland) }\end{array}$ & $\begin{array}{l}\text { Udviklet for German Research } \\
\text { Foundation (DFG) til biblioteker } \\
\text { Interessenter er bevillingsgivere, } \\
\text { universiteter }\end{array}$ & $\begin{array}{l}\text { Ensartede og } \\
\text { offentlige data } \\
\text { for APC udgifter } \\
\text { kan anvendes } \\
\text { ved forhandling } \\
\text { med forlag }\end{array}$ & $\begin{array}{l}\text { Open } \\
\text { Source } \\
\text { github } \\
\text { webtjeneste }\end{array}$ & $\begin{array}{l}\text { Manuel indhentning af } \\
\text { data fra } \\
\text { økonomisystemer af } \\
\text { administrative } \\
\text { medarbejdere }\end{array}$ & $\begin{array}{l}\text { Administrative } \\
\text { udgifter til } \\
\text { personale samt } \\
\text { central support }\end{array}$ & $\begin{array}{l}\text { Kræver IT kompetencer til at } \\
\text { arbejde med github for } \\
\text { central support } \\
\text { Kræver tilladelse til at } \\
\text { offentlige data }\end{array}$ \\
\hline $\begin{array}{l}\text { OpenAPC } \\
\text { Sweden }\end{array}$ & $\begin{array}{l}\text { National } \\
\text { Library of } \\
\text { Sweden } \\
\text { (Sverige) }\end{array}$ & $\begin{array}{l}\text { Biblioteker, universiteter, } \\
\text { bevillingsgivere, politikere }\end{array}$ & $\begin{array}{l}\text { Ensartede og } \\
\text { offentlige data } \\
\text { for APC kan } \\
\text { anvendes til } \\
\text { forhandling } \\
\text { med forlag }\end{array}$ & $\begin{array}{l}\text { Open } \\
\text { Source } \\
\text { github } \\
\text { webtjeneste }\end{array}$ & $\begin{array}{l}\text { Manuel indhentning af } \\
\text { data fra } \\
\varnothing \text { konomisystemer }\end{array}$ & $\begin{array}{l}\text { Administrative } \\
\text { udgifter til } \\
\text { personale samt } \\
\text { central support }\end{array}$ & $\begin{array}{l}\text { Kræver IT kompetencer til at } \\
\text { arbejde med github v. central } \\
\text { support } \\
\text { Kræver tilladelse til at } \\
\text { offentliggøre data }\end{array}$ \\
\hline Chronos & $\begin{array}{l}\text { Chronos } \\
\text { (Danmark) }\end{array}$ & $\begin{array}{l}\text { Specialudviklet til Bill \& Melinda } \\
\text { Gates Foundation, kundegruppen er } \\
\text { primært fonde, biblioteker, } \\
\text { konsortier }\end{array}$ & $\begin{array}{l}\text { Afrapporterings } \\
\text { system for } \\
\text { fonde. } \\
\text { ét samlet one- } \\
\text { stop-shop } \\
\text { system til } \\
\text { submission og } \\
\text { betaling for } \\
\text { forskere }\end{array}$ & $\begin{array}{l}\text { Database, } \\
\text { webservice }\end{array}$ & $\begin{array}{l}\text { Forsker/systemer } \\
\text { leverer data, herunder } \\
\text { mulig integration med } \\
\text { PURE og } \\
\text { økonomisystem }\end{array}$ & $\begin{array}{l}\text { Abonnement } \\
\text { samt } \\
\text { Udgift til lokale } \\
\text { administratorer }\end{array}$ & $\begin{array}{l}\text { "Færdigt" system } \\
\text { Mangler dokumentation for } \\
\text { integration til PURE } \\
\text { Institution ejer data }\end{array}$ \\
\hline
\end{tabular}

Fig. 11: Evalueringsskema over systemløsninger til administration og monitorering af APC data.

Fælles for de fire løsninger er, at de er specialdesignet til at monitorere APC data, dog er implementeringen af dem først sket inden for de(t) seneste (par) år. De to OpenAPC løsninger er dog primært fokuseret på at udstille APC-faktureringsdata på et aggregeret niveau og underst $\varnothing t t e s$ ikke af en egentlig lokal databasestruktur.

Alle de nævnte løsninger kobler publikationsdata og økonomidata og disse metadata vurderes som et $n \varnothing d v e n d i g t$ grundlag for en effektiv APC-monitorering.

Projektgruppen vurderer, at alle disse løsninger vil kunne implementeres i Danmark, men at de alle har forbehold, som der bør tage højde for (jf. skema); særligt ressourceforbrug ved implementering, udvikling, personaleforbrug lokalt og centralt, samt evt. løbende betaling til udbyder.

På workshoppen blev der desuden drøftet behovet for tænke FAIR data principperne ${ }^{27}$ ind $\mathrm{i}$ monitorering af OA-udgifter med særligt henblik på at sådanne genererede data ideelt bør være transparente og åbne og underst $\varnothing$ tte bæredygtige publiceringsmodeller samt systemer, der kan håndtere data. FAIR-principperne (Findable, Accessible, Interoperable, and Re-usable) er udarbejdet med henblik på at sikre ensartede retningslinier og transparens for at at (meta)data er både læsbar og forståelig for både maskiner og mennesker. OpenAPC-løsningen blev på workshoppen præsenteret med henblik på FAIR principperne (se afsnit 4.2.3.2.2)

Andre scenarier for OA monitorering i Danmark:

Nedenfor gives et overblik over andre mulige scenarier til fremtidig OA administration og monitorering på eller for de danske universiteter:

\footnotetext{
${ }^{27}$ Force11 (2016) Guiding Principles for FAIR . Findable, Accessible, Interoperable and Re-Usable Data Publishing (Version B1.0): https://www.force11.org/fairprinciples
} 
- PURE som system til APC administration

PURE muliggør pt inddatering af oplysninger om APC betaling på publikationsniveau. Fordelen vil være, at PURE allerede i dag anvendes af alle danske universiteter. Der mangler dog mulighed for at tilkoble andre regnskabsoplysninger som betalingskilde mv., og der vil skulle udvikles nye metadatafelter i PURE DDF-MXD formatet via Dublin Core. I Tyskland er dette afprøvet med god succes.

- $\varnothing$ konomisystemer til APC administration

Det er muligt at kontere APC udgifter i de eksisterende regnskabssystemer på de danske universiteter. Der er dog ikke knyttet bibliografiske metadata til de enkelte betalinger. Det vil være en stor udfordring at implementere en entydig kontostreng til APC udgifter.

- Estimering af APC udgifter

Det er muligt at lave et estimat på APC udgifter. I indeværende projekt er der lavet et sådant estimat baseret på et udtræk over publikationer fra danske universiteter sammenholdt med listepriser fra forlagene, som vil kunne udstilles til eksempelvis OpenAPC, hvis der åbnes for data, der ikke udelukkende baserer sig på faktureringer. Det kan dog være en udfordring at fastlægge en valid metode, som samtidig sikrer konsistente data på tværs af universiteterne.

Opsamling på spor B.2:

Der er en række mulige løsninger og scenarier i forhold til at administrere og monitorere APC-data, og de involverede universitetsbiblioteker bør ud fra den indledende unders $\emptyset$ gelse vurdere, hvilke løsninger og scenarier, som skal unders $\varnothing$ ges nærmere.

Det anbefales at inkludere andre interessenter i den videre proces, herunder de danske fonde, som skønnes at have samme behov, når det gælder en bedre APC- og Open Access-monitorering. Desuden bør der tages højde for det juridiske aspekt i forhold til at offentligg øre fakturadata fra universiteterne $\varnothing$ konomisystemer samt i forhold til mulige non-disclosure kontrakter med forlag.

Det kan også overvejes efter projektperioden at se på muligheden for en forbedret teknisk databasestruktur koblet op mod OpenAPC. En database (på server) vil samtidigt kunne kobles til licenssystem (ERM el. bibliotekssystem) samt udstille data til visualisering af $\varnothing$ konomi, statistik m.m.

\subsubsection{Udvikle anbefaling til en national best practice på baggrund af institutionernes behov}

Det følgende er et bud på en anbefaling til en national best practice til universiteternes APC-administration. Formålet med en best practice-beskrivelse er at gøre det muligt på både et institutionelt og nationalt plan at danne sig et præcist overblik over det $\varnothing$ konomiske forbrug af 
ressourcer til Open Access-publicering via en ensartet og systematisk APC-administration på tværs af institutionerne.

For at kunne give anbefalinger til en national best practice i APC-håndtering, er det nødvendigt at afklare, hvad institutionernes behov er. Når formålet er monitorering af de nationale publiceringsudgifter til Open Access, må behovene være at sikre en proces, som kan tilvejebringe data, som er ensartede og komplette. Den proces skal være økonomisk rentabel, og den skal kunne gennemføres år for år således, at monitoreringen af udviklingen finder sted kontinuerligt.

Et mål skal være at sikre et workflow til indsamling af data, som samtidigt sikrer sammenlignelige og fuldstændige data. Fordelen ved at basere metoden på APC-data indsamlet fra fx økonomisystemer rundt omkring på institutionerne er præcision.

Men heri består også udfordringen. For giver den nuværende praksis til håndtering af publiceringsudgifter på de danske universiteter forhåbning om, at datakvaliteten allerede nu er af en sådan beskaffenhed, at data kan anvendes til monitorering af publiceringsudgifterne i Danmark? eller er der mulighed for, at datagrundlaget $\mathrm{fx}$ ved oprettelse af unikke kontostrenge til Open Access udgifter kan blive af en sådan kvalitet, at det kan anvendes til monitorering af området?

De spørgsmål er blevet fors $\varnothing$ gt besvaret i projektets Spor B1 via en undersøgelse af nuværende APC-praksis på universiteterne.

Der er mulighed for at monitorere udviklingen i publiceringsudgifter via forskellige systemer. Der findes systemer, som allerede er designede til monitorering af APC-data - en anden løsning kan være at videreudvikle på PURE, så det kan anvendes til indsamling af APC-data.

Fordele og ulemper ved implementering af systemer designet til APC-håndtering er blevet afklaret i projektets Spor B2.

Ligeledes er det muligt at monitorere via høstning og sammenkobling af eksisterende data fra API'er. Denne løsning har projektet brugt til at frembringe estimater på publiceringsudgifter for 2015 og 2016. Det er vigtigt i denne sammenhæng og i forhold til de ovenstående metoder at understrege, at sidstnævnte løsning er et estimat, da det baserer sig på forlagenes aktuelle listepriser, og resultatet vil som følge deraf altid vil være forbundet med en vis usikkerhed.

Anbefalingen er struktureret som følgende:

Først tilvejebringes en opsummering af projektets Spor B1, som gik ud på at 'afdække den nuværende lokale praksis på universiteterne'. Dernæst kommer en opsummering af projektets Spor B2, som skulle 'unders $\varnothing$ ge central APC-administration, invoice-systemer og de udenlandske erfaringer mm.' Til sidst følger de egentlige anbefalinger til en national best practice for APC-administration.

\subsubsection{Spor B1. Afdække nuværende lokal praksis på universiteterne}

For at finde ud af, hvordan de enkelte institutioner håndterer udgifter til publiceringsomkostninger, blev der i forsommeren 2017 gennemført en spørgeskemaunders $\varnothing$ gelse på de enkelte universiteter. 
Unders $\varnothing$ gelsen havde til formål at unders $\varnothing$ ge institutionernes eksisterende praksisser omkring APC-administration.

Det skal nævnes, at svarprocenten for undersøgelsen var relativt lav, men ud fra de svar, som unders $\varnothing$ gelsen rent faktisk genererede, viste den, at:

Betaler din enhed for en eller flere af nedenstående publiceringsomkostninger?

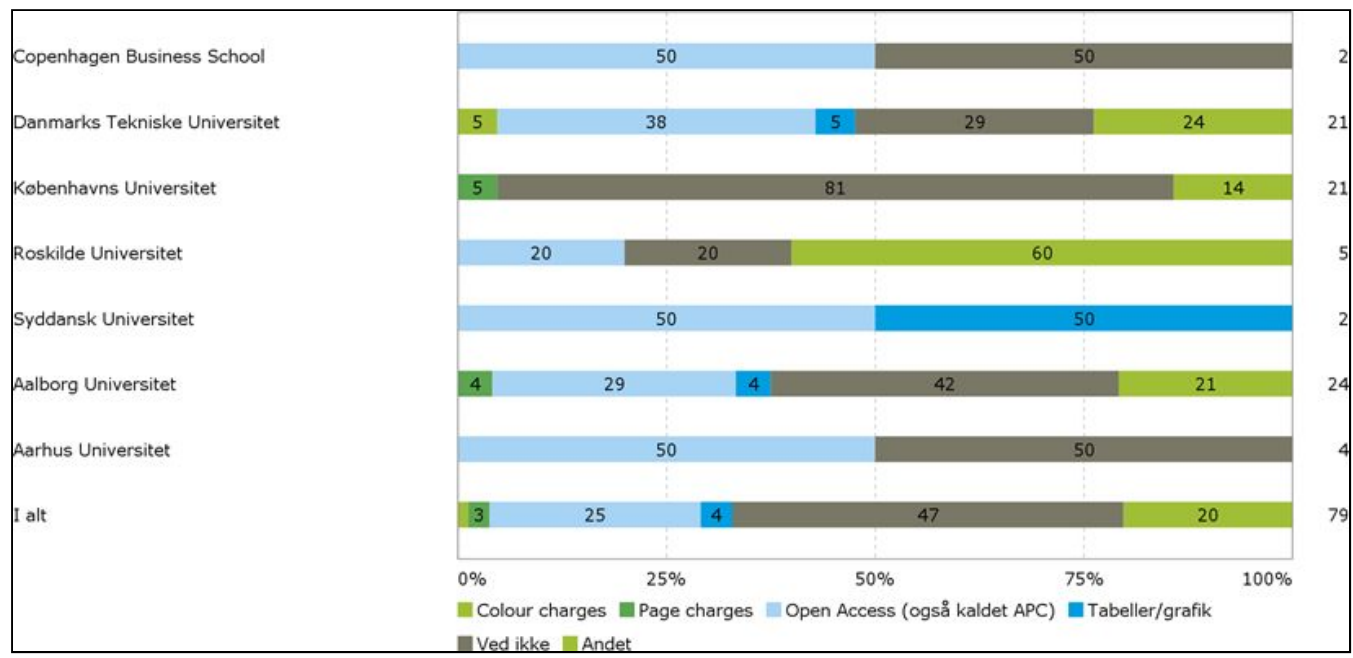

Der hersker stor uvidenhed omkring, hvad der betales for. APC-administration finder ofte sted hos projektadministratorer og økonomifunktioner, der ikke nødvendigvis har den tilstrækkelige viden om publiceringsudgifter dertil hørende begreber som APC, color charges, page charges mv.

\section{Er der fælles retningslinjer for, hvor I konterer publiceringsomkostninger?}

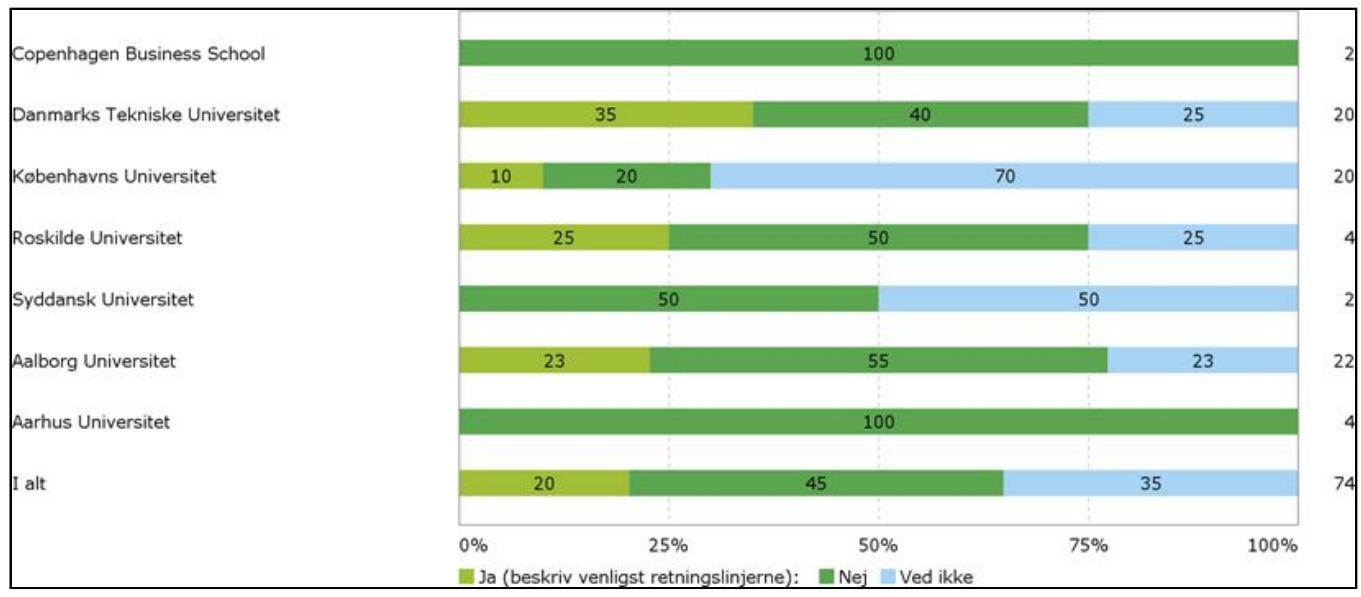

Der er også særdeles uens retningslinjer på de enkelte universiteter. Spørgeskemaunders $\varnothing$ gelsen understreger, at det ikke bare er mellem universiteterne, at der er uens retningslinjer, men også inden for de enkelte universiteter. Hvorvidt det beror på uvidenhed, at der ikke svares ja på de institutioner, hvor der rent faktisk er oprettet en kontostreng, som f.eks. DTU og AAU, kan undersøgelsen imidlertid ikke svare entydigt på. 


\section{Har dit universitet en kontostreng til Open Access betaling?}



Generelt er der kun oprettet kontostrenge til publiceringsomkostninger på få universiteter og det er tvivlsomt, om der fra universiteternes side er vilje til at etablere kontostrenge til håndtering af sådanne alene. Hvis man anvender kontostrenge og henter Open Access fakturadata ud af økonomisystemet med jævne mellemrum, er man desuden stadig afhængig af, at publiceringsfaktura er placeret i den rigtige kontostreng - med andre ord: En kontostreng kan formodentlig ikke gøre det alene.

\section{Konklusion på undersøgelsen:}

Af unders $\varnothing$ gelsen kan det konkluderes, at den nuværende håndtering af fakturaer, som den finder sted på institutionerne, ikke kan udgøre datagrundlaget for monitorering af udgifterne til publiceringsudgifter på nationalt plan, og og det er ligeledes tvivlsomt, om der fremover kan etableres workflows via fx kontostrenge i økonomisystemer, som vil kunne levere ensartede data af en tilstrækkelig kvalitet. Af andre problemer omkring den lokale praksis på universiteterne kan nævnes, at betalinger med kreditkort kan være næsten umulige at opspore samt det vel nok største problem, der ligger i at få adgang til invoice data på universiteterne.

\subsubsection{Spor B2. Undersøgelse af central APC-administration, invoice-systemer, udenlandske erfaringer $\mathrm{mm}$.}

En national løsning på håndtering af APC-administration kunne være implementering af et system, som er designet til at monitorere APC-data. På markedet findes flere forskellige muligheder, der alle har det til fælles, at de først er introduceret inden for de seneste par år og fortsat er under udvikling. Det bærende princip for alle systemer er, at man i et og samme system kobler publiceringsdata med $\varnothing$ konomidata, hvilke skal indeholde og sikre de metadatatyper, som er nødvendige i forbindelse med monitorering.

For at unders $\emptyset$ ge systemernes egnethed til ikke bare APC-administration i al almindelighed, men også APC-administration under danske forhold, blev der i oktober 2017 afholdt en workshop i forbindelse med OAM-DK-projektet, hvor systemerne JISC Monitor Local og Monitor UK, OpenAPC/OpenAPC Sweden og Chronos blev præsenteret og diskuteret.

Det skal som nævnt understreges, at der forud for og på workshoppen blev drøftet at tænke FAIR-principperne ind i arbejdet med monitorering af publiceringsudgifter. I forhold til systemerne 
handler det om at prioritere de systemer og datatyper, som understøtter FAIR-principperne ved at være transparente, åbne og bæredygtige.

\subsection{JISC Monitor Local og Monitor UK}

JISC Monitor Local ${ }^{28}$ og Monitor UK ${ }^{29}$ er hhv. et lokalt og nationalt system til inddatering af publiceringsomkostninger, som er udviklet af Cottage Labs $^{30}$ i samarbejde med JISC Collections til de engelske universitetsbiblioteker, og som har til formål at monitorere APC-udgifter. Monitor Local er sammen med Monitor UK et af en række Open Access services fra JISC Collections ${ }^{31}$, der har til formål at underst $\varnothing$ tte implementering og udbredelsen af Open Access i de engelske universitetsbiblioteker.

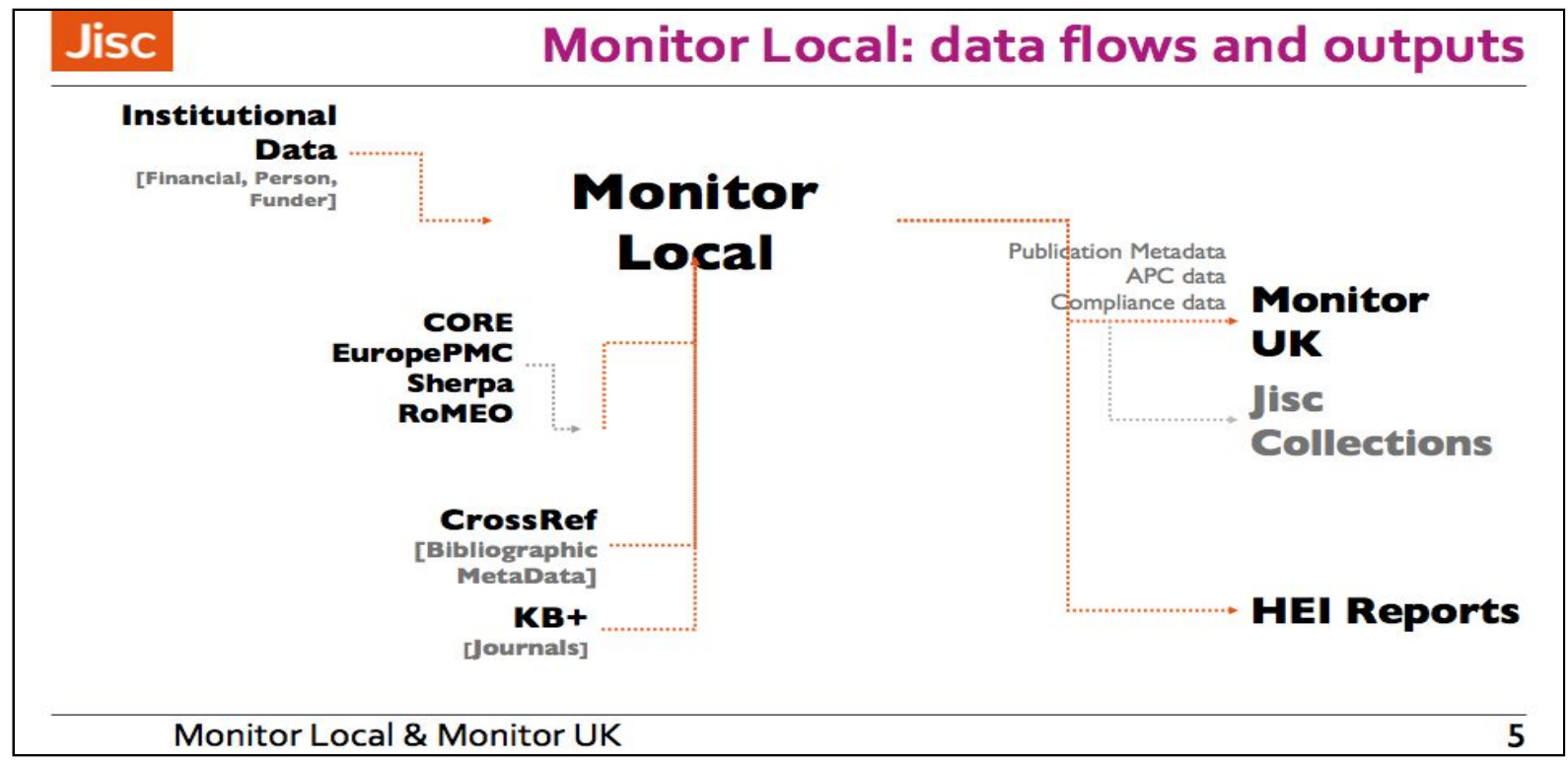

Fig. 12: Monitor Local og Monitor UK: JiSC data flows og output - image credit: Frank Manista, Jisc (UK)

Monitor Local muliggør for de enkelte institutioner at kunne registrere APC-data, mens Monitor UK aggregerer og gør det muligt at udstille engelske APC-data på nationalt niveau. De to systemer kan bruges sammen eller uafhængigt - i forhold til administration af APC-data fokuseres på Monitor Local. Systemet er en database, som kræver manuel inddatering af invoice-data fra forskere eller $\emptyset$ konomisystemer. De enkelte institutioner ejer de inddaterede data. Systemet er tilpasset et publiceringsworkflow og kræver særlige kompetencer som biblioteksansatte besidder.

\footnotetext{
${ }^{28}$ https://monitor.jisc.ac.uk/local/about/

${ }^{29}$ https://monitor.jisc.ac.uk/uk/

30 https://cottagelabs.com/

${ }^{31}$ https://www.jisc.ac.uk/about/who-we-are-and-what-we-do
} 


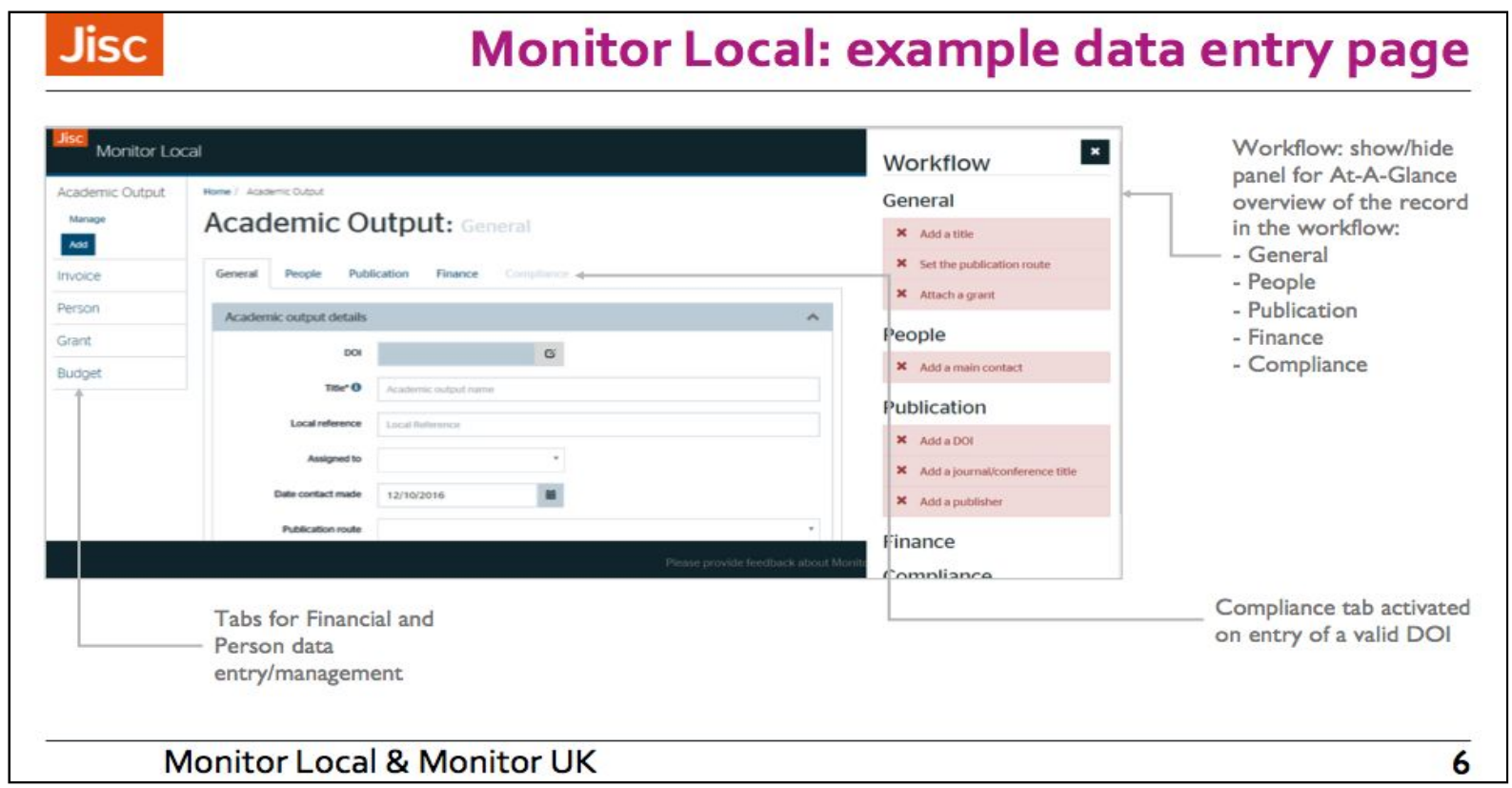

Fig. 13: Monitor Local og Monitor UK: eksempel på indtastning af data - image credit: Frank Manista, Jisc (UK).

Universitetsbibliotekerne i Danmark inddaterer og administrerer ikke på nuværende tidspunkt de offentlige midler til Open Access publicering i modsætning til UK.

Løsningen kræver, at man tegner et abonnement til systemet - og desuden skal påregnes personaleudgifter til inddatering af data.

Konklusion på JISC Monitor Local og Monitor UK:

JISC Monitor Local og Monitor UK er en løsning, som er skræddersyet til engelske forhold, og det vurderes, at det er en løsning, som kræver meget tilretning, før den passer til danske forhold og behov.

\subsection{OpenAPC og OpenAPC Sweden}

OpenAPC ${ }^{32}$ og OpenAPC Sweden ${ }^{33}$ er en open source Github webtjeneste udviklet af Bielefeld University Library med midler fra DFG (Deutsche Forschungsgemeinscaft) ${ }^{34}$ til det støttede projekt, Intact - Transparente Infrastruktur für Open-Access-Publikationsgebühren ${ }^{35}$.

Infrastrukturen er udviklet til biblioteker med henblik på monitorering af APC-udgifter. Formålet er at sikre international monitorering og transparens for APC-invoice data, så de kan anvendes i forbindelse med forhandlinger med forlag.

Tjenesten kræver manuel indhentning af data fra økonomisystemer, og udover udgifter til administrative medarbejdere kræver det stærke IT-kompetencer at håndtere github, workflows m.m.

\footnotetext{
${ }^{32}$ https://github.com/OpenAPC/openapc-de

${ }_{33}$ https://github.com/Kungbib/openapc-se/wiki

${ }^{34}$ https://github.com/OpenAPC/openapc-de

${ }^{35}$ https://intact-project.org/
} 


\section{Workflow for a participating organisation}

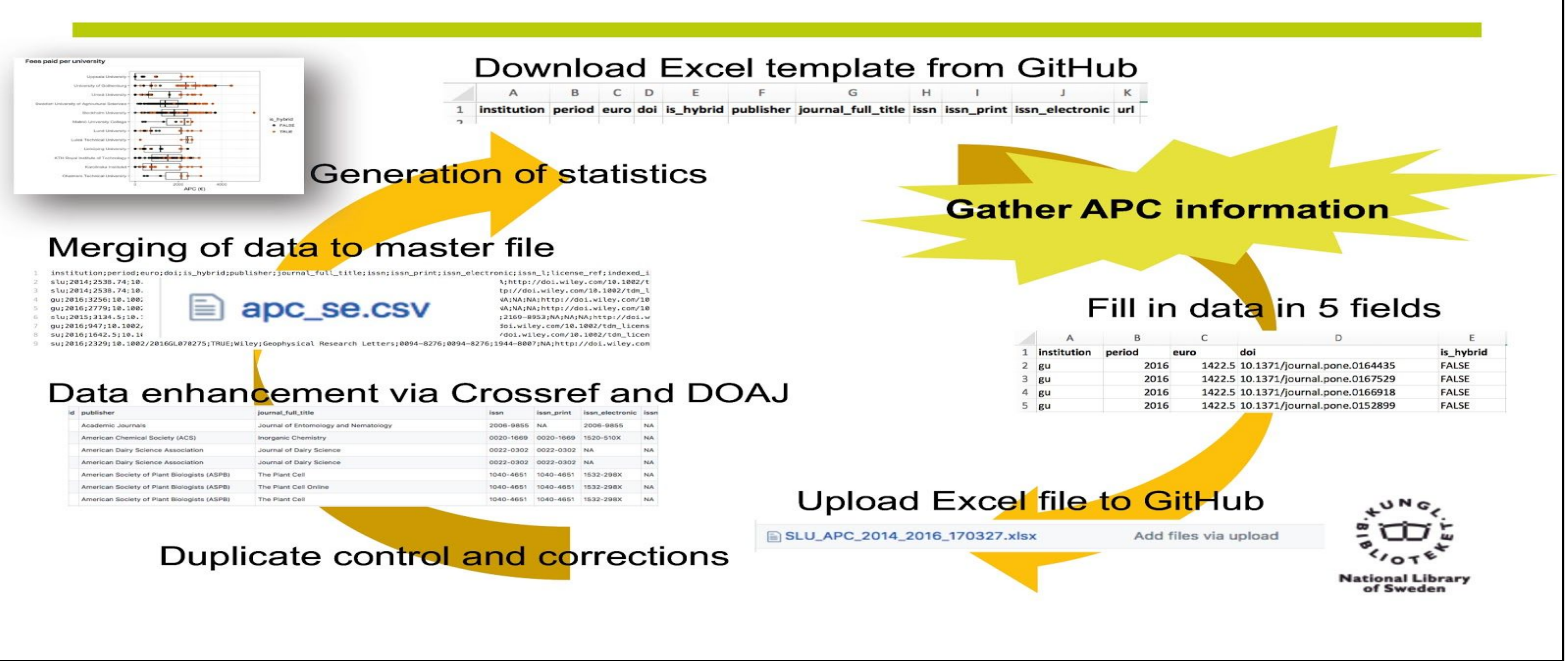

Fig. 14: OpenAPC Sweden: Workflow for deltagende organisationer - Image credit: Ulf Kronman, Kungliga Bibliotek (SE).

OpenAPC lægger vægt på at være en åben og transparent infrastruktur, som man som institutioner kan bidrage til, hvis man ligger inde med APC invoice data, der kan deles. På den måde fors $\varnothing$ ger OpenAPC at aggregere og udstille åbne APC-data både fra universiteter, fundere og fra de større offsetting aftaler med forlag, som nationale konsortier har indgået på vegne af landenes forskningsinstitutioner ${ }^{36}$.

OpenAPC kan anses som en infrastruktur for dataudveksling, der udstiller data efter FAIR principperne, selvom FAIR principperne først senere er kommet til. Dette er klart en styrke og bør være et bærende princip, som andre monitoreringsmekanismer bør følge, og tillige en klar anbefaling fra OAM-DK-projektet.

OpenAPC tegner et ret klart FAIR billede af både data og infrastruktur, som servicen har udviklet sig i projektperioden og som beskrevet nedenfor.

Findable: easy to identify and find for both humans and computers, with metadata that facilitate searching for specific datasets.

\begin{tabular}{|c|c|c|}
\hline F1 & $\begin{array}{r}\text { (meta)data are assigned a globally unique and eternally } \\
\text { persistent identifier }\end{array}$ & DOI \\
\hline F2 & data are described with rich metadata & $\begin{array}{c}\text { Crossref, enrichment with } \\
\text { additional identifiers }\end{array}$ \\
\hline F3 & (meta)data are registered or indexed in a searchable resource & $\begin{array}{c}\text { Dataset is registered in } \\
\text { DataCite }\end{array}$ \\
\hline F4 & (meta)data specify the data identifier & Yes \\
\hline
\end{tabular}

\footnotetext{
${ }^{36}$ https://treemaps.intact-project.org/apcdata/openapc/
} 
Accessible: stored for long term so that they can easily be accessed and/or downloaded with well-defined access conditions, whether at the level of metadata, or at the level of the actual data.

\begin{tabular}{|c|c|c|}
\hline A1 & $\begin{array}{r}\text { (meta)data are retrievable by their identifier using a standardized } \\
\text { communications protocol }\end{array}$ & OLAP Server \\
\hline A1.1 & the protocol is open, free, and universally implementable & Yes \\
\hline A1.2 & the protocol allows for an authentication and authorization procedure, \\
where necessary & Not necessary \\
\hline A2 & metadata are accessible, even when the data are no longer available & Yes \\
\hline
\end{tabular}

Interoperable: ready to be combined with other datasets by humans or computers, without ambiguities in the meanings of terms and values.

\begin{tabular}{|c|c|c|}
\hline I1 & $\begin{array}{r}\text { (meta)data use a formal, accessible, shared, and broadly applicable } \\
\text { language for knowledge representation }\end{array}$ & $\begin{array}{c}\text { Treemaps, plots, lists, } \\
\text { csv, json }\end{array}$ \\
\hline I2 & (meta)data use vocabularies that follow FAIR principles \\
\hline I3 & (meta)data include qualified references to other (meta)data & Article identifiers \\
\hline
\end{tabular}

Reusable: ready to be used for future research and to be further processed using computational methods. This requires adequate information about how the data were obtained and processed (provenance) and an appropriate license.

\begin{tabular}{|c|c|c|}
\hline R1 & $\begin{array}{r}\text { (meta)data have a plurality of accurate and relevant } \\
\text { attributes }\end{array}$ & Not necessary \\
\hline R1.1 & $\begin{array}{r}\text { (meta)data are released with a clear and accessible } \\
\text { data usage license }\end{array}$ & OdBL 1.0 (Open Database License) \\
\hline R1.2 & (meta)data are associated with their provenance & Name of contributing institution \\
\hline R1.3 & (meta)datameet domain-relevant community standards & (?) \\
\hline
\end{tabular}

\section{Konklusion på OpenAPC/OpenAPC Sweden:}

Konklusionen på OpenAPC/OpenAPC Sweden er, at det er en infrastruktur, der primært er egnet til indsamling og visualisering af regulære invoice data, og at der stadig forestår et udviklingspotentiale for arkivering af 'lokale' data eller til sammenkobling i et systemlandskab.

\subsection{Chronos}

Chronos $^{37}$ er et kommercielt produkt særligt udviklet til monitorering for fonde, universiteter og som compliance tool for den enkelte forsker. Løsningen er blevet specialudviklet som et

\footnotetext{
${ }^{37}$ http://chronos-oa.com/?slide=AboutChronos
} 
afrapporteringssystem til Bill \& Melinda Gates Foundation i forbindelse med deres Open Access mandat og program ${ }^{38}$.

Formålet med løsningen er til dels monitorering af APC-udgifter og løsningen kan kaldes en 'one-stop-shop', fordi den håndterer hele processen fra submission til betaling af en Open Access publikation. Således er front-enden af systemet udviklet som både publiceringsværktøj og betalingsværktøj for forskere for at lette deres arbejde ved submission til tidsskrifter og sikring af compliance ift. fondes OA-politikker.

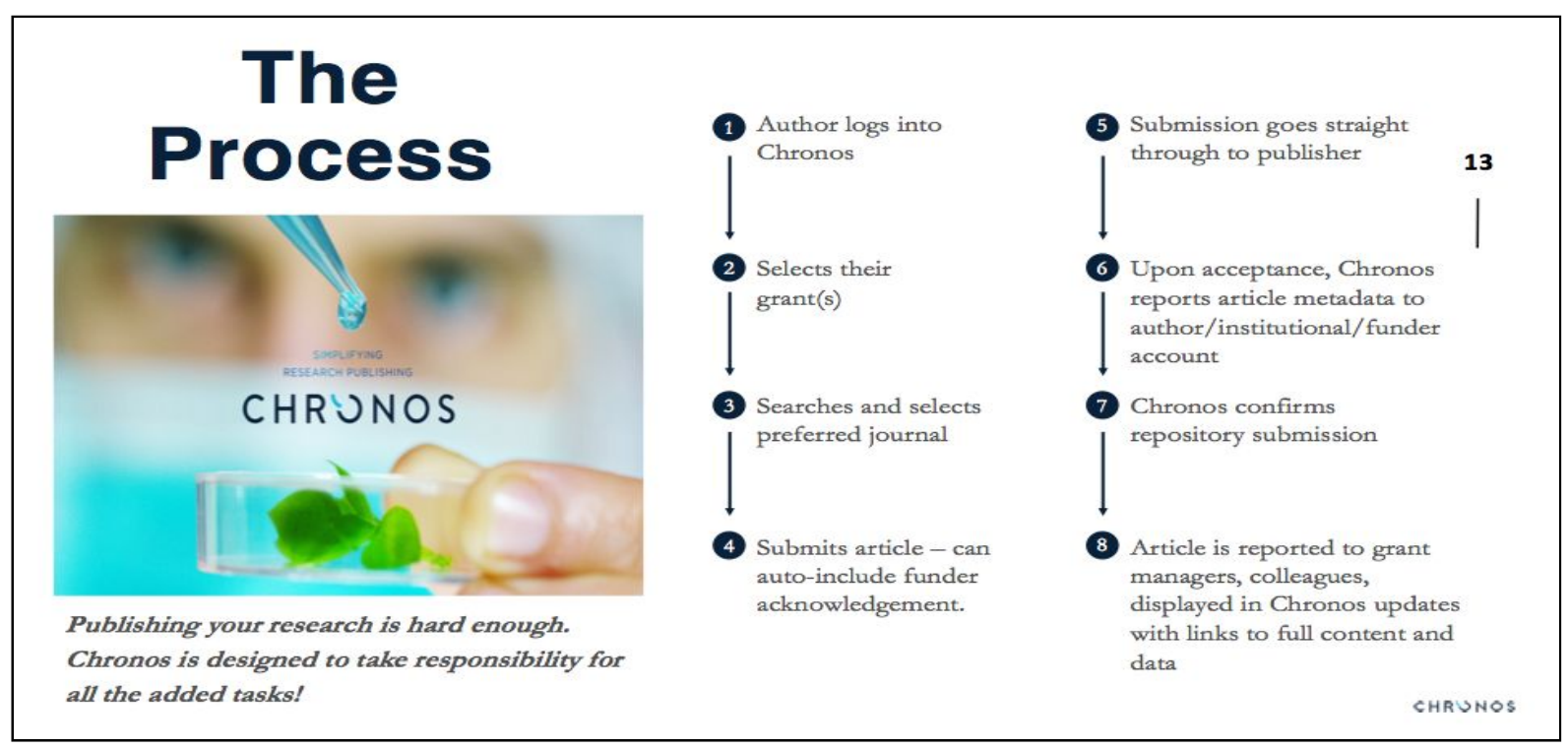

Fig. 15: Chronos' Workflow proces, Image credit: Simon Thomson, Chronos (DK).

Back-end delen af systemet kan f.eks. ligge hos grant management og/eller det enkelte bibliotek, der kan få overblik over og adgang til bevillingsinformation, OA publiceret forskning samt APC-relaterede udgifter. Der er udgifter til abonnement til systemet samt til de lokale administratorer af systemet.

Konklusion på Chronos:

Det er usikkert, om man med introduktionen af et nyt administrativt system kan forvente tilstrækkelig opbakning blandt VIP-personale, der garanterer en systematisk APC-monitorering. I en dansk kontekst vil Chronos muligvis kunne integrere sig til PURE, men der mangler dokumentation, da denne kobling endnu ikke er blevet afprøvet.

\subsubsection{Opsummerende på de ovenfor beskrevne løsninger}

I forbindelse med opfølgning på workshoppen blev det vurderet, at alle fire systemer i princippet vil kunne implementeres i Danmark til håndtering af APC-data, men i evalueringen af dem, er det endnu præmaturt og forbundet med en vis usikkerhed at anbefale eller anvende systemerne. Nogle af systemerne er således endnu ikke tilstrækkeligt gennemtestede, og der vil være større ressourcemæssige omkostninger forbundet med implementering og drift af systemerne i Danmark. Ud over FAIR principperne som en god guideline for krav til en løsning, er sustainability blevet vurderet som en anden. Det fordrer en afklaring på spørgsmål, som hvorvidt en løsning kan skaleres,

\footnotetext{
${ }^{38}$ https://chronos.gatesfoundation.org/
} 
workflows er dokumenteret og de driftsmæssige aspekter vedrørende support og vedligehold er dokumenteret.

Det er desuden blevet overvejet, om PURE som alle danske universiteter benytter som CRIS, kunne tages $i$ anvendelse som system til indsamling af APC-data. Fordelen ved PURE er, at alle institutioner i forvejen arbejder med systemet og kender det indefra, samt at der i PURE installationerne allerede er aktiveret et APC-felt.

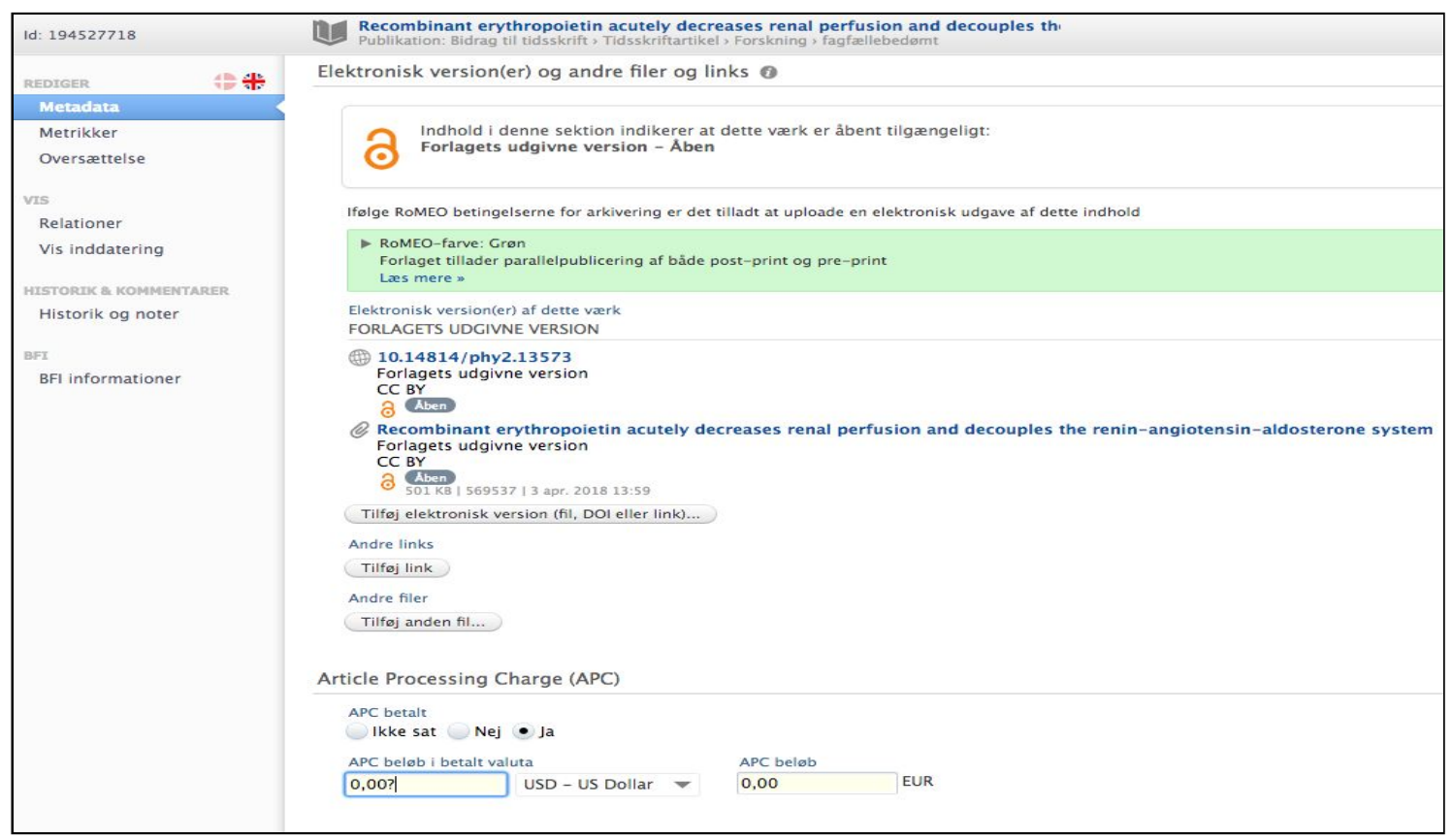

Fig. 15: PURE data template: eksempel på indtastning af data i APC felt

Komplikationen ved PURE er imidlertid, at systemet ikke er klart til at modtage alle de metadata, som aggregeres via OAM-DK-metoden (se OAM-DK data template) og at det nationale udvekslingsformat via metadataskemaet (DDF-MXD) ${ }^{39}$ vil kræve et ændringsforslag, der godkendes på tværs af PURE Styregruppen i Danmark. Ydermere er det fortsat usikkert, om dette ville føre til et mere præcist og dokumenteret overblik over APC-betalinger, da det primært ville være forskerne selv, der skal registrere beløbene.

Det skal imidlertid nævnes, at der med succes er blevet arbejdet med CRIS-systemer til udveksling og håndtering af APC-data i Tyskland. Bl.a. udviklingen af en kravspecifikation på et metadataskema, der kan udveksles via protokollen, OAI-PMH ${ }^{40}$, som de fleste CRIS og repositorier anvender per se.

Da ingen systemer pt. anses som fuldt flyvefærdige i forhold til monitorering af APC-data af de ovenfor nævnte grunde, er det projektets holdning, at monitorering i Danmark fortsat bør ske ved brug af den metode, som er blevet udviklet i løbet af OAM-DK-projektet, der giver et rimeligt estimat over publiceringsudgifter for de danske universiteter.

\footnotetext{
${ }^{39}$ DDF-MXD (Danish Research Database Metadata Exchange Format for Documents), v. 1.4.1, 15.7.2018: http://mx.forskningsdatabasen.dk/mxd/current/DDF MXD v1.4.1.pdf

${ }^{40}$ Deinzer, Gernot, Wagner, Alexander, Broschinski, Christoph, \& Pieper, Dirk. (2017). Including Open Access Information in institutional repositories. Zenodo. http://doi.org/10.5281/zenodo.887318
} 
Disse data vil i et nyt konsolideringsprojekt blive fors $\varnothing$ gt aggregeret via en en forbedret og mere automatiseret metode i en til formålet designet database, der kan give institutionerne mulighed for at udstille og visualisere forskellige typer af data til lokale formål (jvf. forrige afsnit 4.1.5.1).

\subsubsection{Anbefalinger til national best practice (B.3)}

De ovenstående konklusioner fra de tre arbejdsspor i projektets hovedfase B: Identifikation og udvikling af best practice for APC-administration fører til følgende anbefalinger:

- Det kan for nuværende ikke anbefales at basere monitorering på data fremskaffet via en lokal APC-praksis

- Det kan for nuværende ligeledes ikke anbefales at abonnere på systemer under udvikling som f.eks JISC Monitor Local/Monitor UK, OpenAPC/OpenAPC Sweden og Chronos, idet de enten ikke er tilstrækkeligt gennemtestede, kræver invoice data samt for mange ressourcer på at implementere og drifte dem.

- Det kan ligeledes ikke anbefales på nuværende tidspunkt at anvende PURE til indsamling af APC-data, idet systemet ikke kan håndtere de nødvendige typer af metadata.

- Det anbefales i stedet, at monitorering for nuværende finder sted via den API-baserede metode, som er udviklet i OAM-DK-projektet.

- Da monitorering via OAM-DK-projektets metode er et estimat (se ovenstående), anbefales det, at der arbejdes videre på at sikre en administrativ håndtering af APC-data, som er præcis, valid og tilstrækkelig.

- Det anbefales desuden at etablere en APC-database, der vil sikre opbevaring, aggregering og udstilling af de indsamlede APC-data til gavn for interne processer som eksterne interessenter.

- Projektet anbefaler en SQL-database som Iøsning, da den er enkel at arbejde med og sikrer, at data kan opbevares, genbruges og udstilles.

- Det anbefales, at fremtidig APC-monitorering organisatorisk bliver et ansvarsområde $\mathrm{i}$ forskningsbibliotekerne, da det er her, at kernekompetencerne til at kvalitetssikre monitorering af Open Access er til stede. 


\section{Konklusion}

Af de tre udvalgte og afprøvede metoder i projektet til at kortlægge den samlede publiceringsøkologi - og økonomi for Open Access på de danske universiteter, er den i projektet udviklede komputationelle identifikation af Open Access via scripts, der høster metadata fra 3. part kilder, den mest effektive og præcise. Det anbefales at automatisere så megen dataindsamling og validering som teknisk muligt, da det sikrer en højere kvalitet i data, omend en del manuelle opslag, normalisering og validering af data, fortsat kræver et trænet øje med know-how om kompleksiteten i Open Access.

Som en best practice har projektet udviklet en udførlig guideline til indsamling af bibliografiske metadata og APC-data baseret på kurante listepriser til en til formålet udviklet data template og en vejledning til beregninger af institutionelle udgifter til Open Access, som alle universiteter har gennemført. Med den udviklede estimeringsmetode i projektet, er de deltagende universiteter i stand til at monitorere deres publicerings økologi -og økonomi uden om faktureringsdata, der vil kræve oprettelse af nye kontostrenge og en ensartet konteringspraksis, som på nuværende tidspunkt ikke forekommer. På sigt bør det være et mål at udvikle en ensartet og entydig konteringspraksis.

OA Monitor-data vil aldrig være $100 \%$ præcise, da de baserer sig på et estimat, men med projektets afslutning foreligger der for første gang et nationalt overblik på omfanget af gylden og hybrid Open Access-publicering og de økonomiske omkostninger forbundet hermed for publiceringsåret 2016.

Danmark og universiteterne har en grøn OA strategi, der overvejende beror på selvarkivering af forskerens accepterede og peer reviewede manuskripter. OAM-data viser, at gylden og hybrid OA nationalt i 2016 udgør mere end $75 \%$ point (6487 artikler) i gennemsnit af den realiserede Open Access i OA Indikatoren (8444 artikler), der nationalt ligger på $36 \%$. Andelen af gylden og hybrid OA varierer afhængigt af universiteternes publiceringsmønstre og valideringen af OA-type ud fra OAM-DK data.

Dvs. virkeligheden for realisering af Open Access ved de danske universiteter i højere grad sker ad den gyldne (4252 artikler, $69 \%$ point) og hybride (2235 artikler, 31\% point) vej. Dette forklarer en forholdsvis høj andel af Open Access udgifter, hvor APC estimeres at udgøre over $20 \%$ af udgiften for universiteternes samlede licensportefølje, der årligt løber op i ca. 160 mio. kr. Udgiften til hybrid APC udgør ca. 8\% point, mens den gyldne andel af APC udgør ca. $13 \%$ point. Beløbene skal tages med en række forbehold bl.a. grundet anvendelse af listepriser og variationer $\mathrm{i}$ anvendelse af metoden (jvf. afsnit 4.1.4). Enkelte universiteter har også været i stand til at levere et benchmark for 2015 og 2016 data, der generelt viser en stigende udgift til Open Access for de respektive universiteter.

OAM-DK er et monitoreringsprojekt, hvis formål har været at fremskaffe bedre metadata om OA publicering og dermed også implicit øge institutionernes OAI tal. OAM data kan både $\varnothing$ ge indsigten og bevidstheden hos universiteterne og løftes til det strategiske niveau men også helt lavpraktisk i form af forbedret forskningsregistrering af universiteternes Open Access. OAM-DK data kan ligeledes være en medvirkende faktor for en reduktion af licenspriser, men det forudsætter meget præcise data og at institutionerne pt. selv $\varnothing$ nsker at forhandle det med ind i aftalerne. 
Effekten af nærværende projekt er i en opfølgende konsolidering at få etableret en kravspecifikation på en OA Monitor database og en OA Monitor Analytics applikation, der med et mere automatiseret workflow vil kunne levere real time monitorering af både typer af OA publikationer og udgiftsdata. Projektet anbefaler, at det undersøges, hvordan OAM data kan tænkes ind i og om muligt integreres og blive interoperable med allerede eksisterende og relaterede systemkomponenter -og services, der anvendes i universiteternes systemkompleks. Som evidensbase kan OA Monitor for fremtiden være med til at understøtte grundlaget for beslutningsprocesserne både i universiteternes og det nationale strategiske arbejde med at nå i mål med den danske Open Access strategi.

Da ingen af de tekniske systemløsninger i anvendelse på markedet, som projektet har unders øgt, på nuværende tidspunkt vurderes at kunne leve op til målet, er det projektets holdning, at monitorering i Danmark fortsat bør ske ved brug af den udviklede OAM-metode. Det anbefales samtidigt, at OA monitorering organisatorisk bliver et ansvarsområde i forskningsbibliotekerne, da det er her, at kernekompetencerne til at kvalitetssikre monitorering af Open Access er til stede.

\section{Perspektivering}

Som udviklingen i tiltag på både et europæisk plan og nationalt niveau har vist, er aktørerne involveret i finansieringen såvel som tilvejebringelsen og evalueringen af forskning, optaget af at kunne monitorere effekten af både private som offentlige politikker og investeringer i Open Access. Senest har EC lanceret en Open Science Monitor ${ }^{41}$ med målet om at kunne levere data og indsigt $\mathrm{i}$ andre typer af åbne bidrag ud over publikationer, der anses som en nødvendighed for at underst $\varnothing t$ te implementeringen af ECs Open Science politik.

På samme måde kan OA Monitor fremadrettet bidrage til indsamlingen og monitoreringen af andre typer output som mulig evidens for udviklingen og omkostningerne hen imod en bredere Open Science kultur og praksis i forskningen. Realiseringen af dette er nødvendigvis betinget af adgangen til den infrastruktur og de typer af data, som vil komme til at levere og også kunne måle brugen af forskningens indhold.

En oplagt knopskydning på resultaterne og erfaringerne fra OAM-DK projektet er, ud over konsolideringen af OA Monitor og OAM Analytics, at inkludere indsamlingen af impact, forstået som citationer, brug og download, af Open Access publikationer, der hidtil ikke har været systematisk analyseret for og på de danske universiteter over tid. Andre data points kunne være at indsamle acknowledgements fra artikler i forhold til at tegne et klarere billede af, hvem der egentlig finansierer Open Access publicering i Danmark.

Det vil endvidere være værd at unders $\varnothing$ ge om nye lancerede mega-indekser som Dimensions ${ }^{42}$ eller 1 Findr ${ }^{43}$ enten vil kunne supplere eller afløse de kilder, som OAM-metoden gør brug af og om de vil kunne tilføje flere oplysninger, end der hentes for nuværende. Indeksering af Open Access er et dynamisk felt med mange nyudviklinger, hvorfor workflows og metoder til identifikation løbende bør

\footnotetext{
${ }^{41}$ EC (European Commission): Open Science Monitor: Updated methodological note, Brussels, Oct. 8, 2018 : https://ec.europa.eu/info/sites/info/files/methodologicalnote rev-second versionpub for publication-converted.pdf ${ }^{42}$ https://www.dimensions.ai/

${ }^{43}$ https://www.1science.com/1findr/
} 
tages op til revision.

Endeligt bør OAM-data sammen med aggregering af andre eksisterende Open Access metadata skubbes ud til forskere som relevant information forud for submission af artikler og på den måde levere just-in-time information via en webservice, der vil kunne lette valget af publiceringskanal, hvad enten forskeren publicerer Open Access eller ej.

Sådanne tiltag vil dog kræve, at universiteterne er i stand til at sikre et organiseret samarbejde mellem de kompetencer, der er til stede inden for system-it, dataanalyse, bibliometri, licens, OA samt forskningsregistrering på universiteterne. Som OAM-DK projektet har vist, er dét at arbejde systematisk med processer fra udvælgelse, adgang, indsamling, tilpasning, integration og anvendelse af data at træde ind i nyt territorium, der samtidigt kræver videreudvikling af eksisterende kompetencer.

En måde at sikre det på internt og blandt institutioner kunne være at indgå mere aktivt i communities som $\mathrm{fx}$ Carpentries ${ }^{44}$ der arbejder bredt med certificering inden for kodning, dataanalyse, data science og software, og i fællesskab tilegne sig færdigheder, der vil muligg øre mere dataintensivt samarbejde og kompetenceudvikling og på den måde være i stand til at kunne skabe noget større og mere skalerbart sammen på tværs ved at bruge hinanden.

I det længere perspektiv må fors $\emptyset$ g, der påtænker at harmonisere monitoreringen af Open Access og også bredere Open Science være skalerbar ud fra som minimum FAIR data standarder og basere sig på, at adgang og indsamling kan foregå via åbne API'er, åbne fil-formater og åben licenserede databaser. Nærmere betegnet må monitorering af Open Access og Open Science være åben per se, ellers vil monitorering ikke ramme og nå i mål.

\footnotetext{
${ }^{44}$ The Carpentries består af Library, Data og Software Capentry, der tidligere var selvstændige initiativer: https://carpentries.org/
} 


\section{Referencer}

cOAlition S (2018): Making Open Access a reality by 2020 - A Declaration of Commitment by Public Research Funders (September 4, 2018): https://www.scienceeurope.org/coalition-s/

Danske Universiteter (2018): Danske universiteter går til Vestager for at stoppe forlagsmonopol, pressemeddelelse, 6. nov. 2018:

https://dkuni.dk/pressemeddelelser/danske-universiteter-gaar-til-vestager-for-at-stoppe-forlagsmo nopol/

DDF-MXD (Danish Research Database Metadata Exchange Format for Documents), v. 1.4.1, 15.7.2018: http://mx.forskningsdatabasen.dk/mxd/current/DDF MXD v1.4.1.pdf

DEFF (2016): Åbenhed, adgang og deling, DEFF workshop, 9. marts, 2016:

https://www.deff.dk/fileadmin/user upload/DEFF/dokumenter/strategi og samarbejde/DEFF-Wor kshop/Deff Strategi Beta.pdf

Deinzer, Gernot, Wagner, Alexander, Broschinski, Christoph, \& Pieper, Dirk. (2017). Including Open Access Information in institutional repositories. Zenodo. http://doi.org/10.5281/zenodo.887318

European Commission(2018): Open Science Monitor: Updated methodological note, Brussels, Oct. 8, 2018:

https://ec.europa.eu/info/sites/info/files/methodologicalnote rev-second versionpub for publicati on-converted.pdf

EUA (2018): Scholarly publishing: EUA asks European Commission to investigate lack of competition, press release, Nov 6, 2018:

https://eua.eu/news/188:scholarly-publishing-eua-asks-european-commission-to-investigate-lack-of -competition.html

Force11 (2016): Guiding Principles for FAIR - Findable, Accessible, Interoperable and Re-Usable Data Publishing (Version B1.0): https://www.force11.org/fairprinciples

OpenAIRE (2017): Impact and Measurement of Open Access, HiOA, Oslo (14.2.2017):

https://www.openaire.eu/openaire-workshop-impact

Stern, N. \& Knowledge Exchange (2016): Knowledge Exchange consensus on monitoring Open Access publications and cost data: Report from workshop held in Copenhagen 29-30 November 2016:

http://www.knowledge-exchange.info/event/oa-monitoring

Svendsen, M., \& H. Thomasen, C. (2017). Knowledge Exchange Consensus: Monitoring of Open Access Publications and Cost Data. Conference abstract for the 46th LIBER Annual Conference, Patras, Greece: http://liber2017.library.upatras.gr/programme/ 
Svendsen, M., Hansen, L. A. J., \& Andersen, D. (2017). Open Access Monitor - DK: Case: University of Copenhagen, 2015 data. Poster presented at the poster session of the Annual Meeting of Danish Research Libraries Association, 2017, DOI: 10.5281/zenodo.896132

Svendsen, M., Rosenkrantz Hansen, C, \& Andersen, D. (2018): Open Access Monitor - DK: Concluding Conference \& Executive Summary, DOI: 10.5281/zenodo.1544953

Van der Graaf, M \& Knowledge Exchange (2017): Paying for Open Access: The author's perspective, DOI: $10.5281 /$ zenodo.438037

For en mere omfattende baggrund af udvalgte referencer til Open Access monitorering henvises til denne bibliografi: https://www.zotero.org/groups/698934/apcbibliografi

\section{Appendix}

1. OAM workshops - program

2. B-01: Open Access - Rapport om forretningsmodeller på markedet

3. Kortlægningsskema (adgang efter anmodning via FC - Forskningsbibliotekernes Chefkollegium)

4. Open Access Monitor - guideline til dataindsamling (v.1.0)

5. Vejledning til beregninger i OAM-projektet

6. OAM integrationsmuligheder

7. B.1 - Spфrgeskema ( $\varnothing$ konomisektioner)

8. B.1 - Spфrgeskema (udvalgte institutter)

9. OAM beregninger 2016 (adgang efter anmodning via FC -Forskningsbibliotekernes Chefkollegium)

10. Rapport: LOA (Licens \& Open Access) 2018 - Stockholm

11. OAM-DK afsluttende konference - program

\section{Figurer}

Fig. 1: Workflow proces for OAM-metoden.

Fig. 2: Evaluering fra workshoppen af egnethed og læring ift. OAM kogebog.

Fig. 3: OA Monitor software komponenter.

Fig. 4: PostgreSQL interface, ex. på strukturering af OAM 2016 data.

Fig. 5: Sql query i Falcon for hybrid APC.

Fiq. 6: Ex. på scatterplot for hybride APC i USD, (Københavns Universitet, 2015).

Fiq. 7: Ex. på boxplot for gold og hybrid APC i USD, (Københavns Universitet, 2015).

Fiq. 8: Excel interface for dataimport fra PostgreSQL.

Fig. 9: Metabase - APC dashboard: udgivers (\%) andel af hybride APC.

Fig. 10: Metabase - APC dashboard: udgivers andel (\%) af hybride og gold APC.

Fiq. 11: Evalueringsskema over systemløsninger til administration og monitorering af APC data.

Fiq. 12: Monitor Local og Monitor UK: JiSC data flows og output (Image credit: Frank Manista, Jisc)

Fig. 13: Monitor Local og Monitor UK: eks. på indtastning af data (Image credit: Frank Manista, Jisc)

Fig. 14: OpenAPC Sweden: Workflow for deltagende organisationer (Image credit: Ulf Kronman, KB)

Fig. 15: Chronos' Workflow proces (Image credit: Simon Thomson, Chronos, DK). 